\title{
WORK PLAN FOR PRELIMINARY INVESTIGATION OF ORGANIC CONSTITUENTS IN GROUND WATER AT THE NEW RIFLE SITE RIFLE, COLORADO
}

January 1996

Work performed under DOE Contract No. DEAC04-91AL62350

\author{
Prepared for \\ U.S. Department of Energy \\ Albuquerque Operations Office \\ Grand Junction Projects Office \\ Prepared by \\ Jacobs Engineering Group Inc. \\ Albuquerque, New Mexico
}

\section{DISCLAIMER}

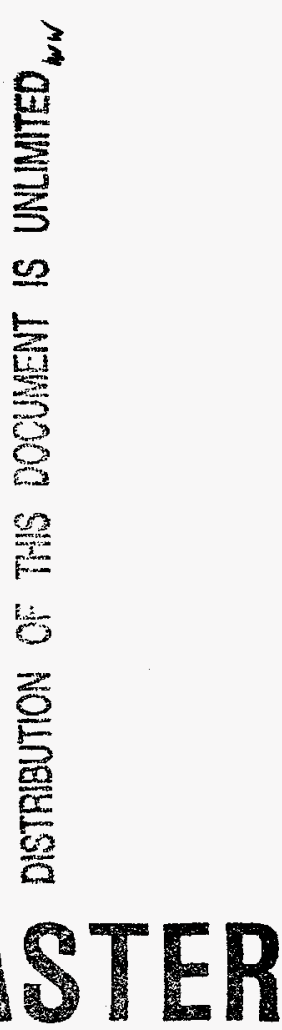

This report was prepared as an account of work sponsored by an agency of the United States Government. Neither the United States Government nor any agency thereof, nor any of their employees, makes any warranty, express or implied, or assumes any legal liability or responsibility for the accuracy, completeness, or usefulness of any information, apparatus, product, or process disclosed, or represents that its use would not infringe privately owned rights. Reference herein to any specific commercial product, process, or service by trade name, trademark, manufacturer, or otherwise does not necessarily constitute or imply its endorsement, recommendation, or favoring by the United States Government or any agency thereof. The views and opinions of authors expressed herein do not necessarily state or reflect those of the United States Government or any agency thereof. 


\section{DISCLAMIER}

Portions of this document may be illegible in electronic image products. Images are produced from the best available original document. 


\section{TABLE OF CONTENTS}

Section

Page

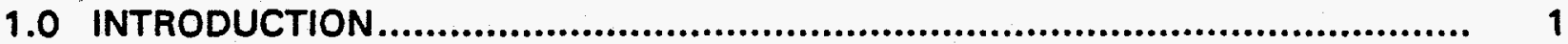

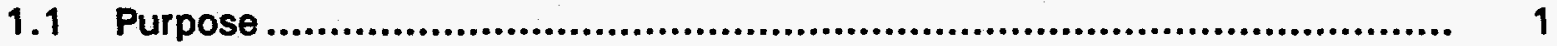

1.2 Background information.............................................................. 1

1.3 Data collection objectives................................................................ 2

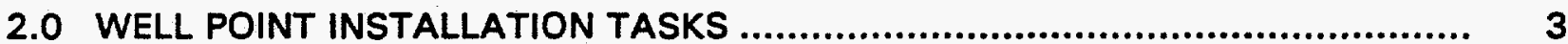

2.1 Site conditions ............................................................................ 3

2.2 Well point locations ............................................................... 3

2.3 Permits, clearances, and access agreements .................................... 6

2.4 Well installation methods............................................................... 6

2.5 Well development ................................................................... 8

2.6 Surveying ................................................................................. 8

2.7 Water sampling and analysis......................................................... 9

2.8 Site restoration........................................................................... 10

2.9 Field documentation................................................................... 10

2.10 Anti-contamination measures..................................................... 11

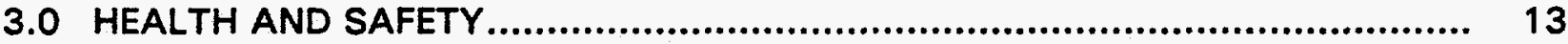

3.1 Site-specific health and safety measures........................................ 13

3.2 Health and safety audits............................................................... 14

4.0 WELL INSTALLATION TASK SCHEDULE.......................................... 15

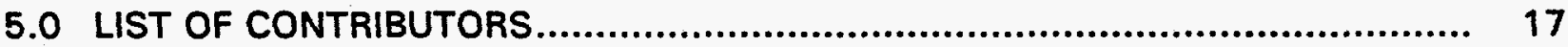

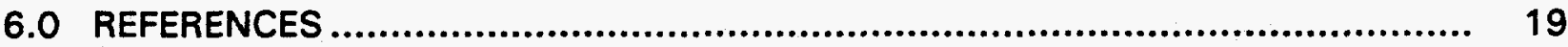

$\begin{array}{ll}\text { ATTACHMENT } 1 & \text { RESULTS OF 1989 APPENDIX IX SCREENING } \\ \text { ATTACHMENT } 2 & \text { MK-FERGUSON ORGANIC ANALYSIS } \\ \text { ATTACHMENT } 3 & \text { FINAL GRADING PLAN } \\ \text { ATTACHMENT } 4 & \text { WORK ORDER }\end{array}$




\section{LIST OF FIGURES}

Figure

Page

2.1 Water table contour map of the alluvial aquifer, New Rifle, Colorado, processing site vicinity.

2.2 Locations of proposed monitor wells, New Rifle, Colorado, site ..........................

\section{LIST OF TABLES}

Table

Page

2.1 Approximate northing and easting coordinates for proposed well points (based on MK-F construction coordinates) 


\section{LIST OF ACRONYMS}

Acronym

DCO

DOE

EPA

FTR

GC

MS

PID

PRS

PVC

RAC

RCRA

SOP

TAC

UMTRA

\section{Definition}

data collection objective

U.S. Department of Energy

U.S. Environmental Protection Agency

field technical representative

gas chromatography

mass spectrometry

photoionization detector

project regulatory specialist

polyvinyl chloride

Remedial Action Contractor

Resource Conservation and Recovery Act

standard operating procedure

Technical Assistance Contractor

Uranium Mill Tailings Remedial Action 


\subsection{INTRODUCTION}

\section{1 - PURPOSE}

A special study screening for Appendix IX (40 CFR Part 264) analytes identified the New Rifle site as a target for additional screening for organic constituents. Because of this recommendation and the findings in a recent independent technical review, the U.S. Department of Energy (DOE) has requested that the Technical Assistance Contractor (TAC) perform a preliminary investigation of the potential presence of organic compounds in the ground water at the New Rifle Uranium Mill Tailings Remedial Action (UMTRA) Project site, Rifle, Colorado. From 1958 to 1972, organic chemicals were used in large quantities during ore processing at the New Rifle site, and it is possible that some fraction was released to the environment. Therefore, the primary objective of this investigation is to determine whether organic chemicals used at the milling facility are present in the ground water.

The purpose of this document is to describe the work that will be performed and the procedures that will be followed during installation of ground water well points at the New Rifle site. The selection of analytes and the procedures for collecting ground water samples for analysis of organic constituents are also described.

\subsection{BACKGROUND INFORMATION}

Sampling for organic compounds was performed at New Rifle and other sites early in 1989 and the results were reported in an 8 November 1989 letter from the TAC to the DOE (Attachment 1). Samples of tailings and ground water were analyzed for Appendix IX (40 CFR Part 264) analytes; traces of several chemicals, including 2,4,5-T, di-n-octylphthalate, and toluene were reported in New Rifle ground water. In addition, there have been reports of black (possibly organic) materials in some soils and sheens on the water surface during subpile test pitting and during later stages of surface remediation. While neither of these characteristics is definitive regarding composition or source, MK-Ferguson has commissioned analysis of several soil samples and petroleum hydrocarbons have been quantified in the $\mathbf{4 0 0 0}$ to $\mathbf{5 0 0 0}$ milligram per kilogram $(\mathrm{mg} / \mathrm{kg})$ range (Farquhar, 1995) (Attachment 2). Sample collection protocol and laboratory quality assurance/quality control $(\mathrm{QA} / \mathrm{OC})$ procedures that were followed in the generation of these data are unknown.

Even though the Appendix IX list provides coverage of most Resource Conservation and Recovery Act (RCRA)-regulated hazardous chemicals that are commonly monitored in an aqueous medium, it does not provide straightforward coverage of complex mixtures such as kerosene or No. 2 fuel oil, which were process carrier chemicals used in large quantities at many UMTRA sites. The Appendix IX list also does not cover many of the extracting solvents commonly 
used in uranium milling, notably di(2-ethylhexyl)phosphoric acid and tributyl phosphate in the case of New Rifle.

Although no specific toxicological information on di(2-ethylhexy)phosphoric acid has been located, other organophosphorus esters, including tributyl phosphate, have been identified as potentially hazardous to human health (Casarett and Doull, 1991; Sabine and Hayes, 1952; Gerhart et al., 1993; EPA, 1989; Laham et al., 1985; Laham et al., 1984; Laham et al., 1983; Proctor et al., 1988). Other potentially toxic extractants such as high-molecular-weight secondary and tertiary amines could also have been used at the site (Merritt, 1971; EPA, 1980; AlHAAP, 1962; HYDRA, 1978; Eder et al., 1979). EPA does not list these specific organic compounds in Table 1 to Subpart A or Appendix 1 of 40 CFR 192; however, more commonly used organic compounds of this class are present in Appendix I to 40 CFR Part 192. Therefore, due to potential for toxicity, TAC will screen for these compounds.

\subsection{DATA COLLECTION OBJECTIVES}

Data collection objectives (DCO) identify reasons for collecting data. Following are DCOs for the assessment of organic constituents at the New Rifle site:

- Ground water quality screening for the presence or absence of kerosene or No. 2 fuel oil (process carrier chemicals that likely were used in large quantities) in ground water near likely source areas at the New Rifle site. This will include screening for the benzene, toluene, ethylbenzene, xylene component and other constituents that are included in the Appendix IX list.

- Ground water quality screening for the presence or absence of extracting solvents commonly used in uranium milling (notably di(2-ethylhexyl)phosphoric acid and tributyl phosphate) in ground water near likely source areas at the New Rifle site.

- Ground water quality screening for inorganic contaminants that may or may not be associated with organic constituents at the New Rifle site.

- Ground water quality screening for the presence or absence of organic constituents upgradient of locations that may have been the focus of processing-related activities in order to assess the potential for other, non-UMTRA sources of organic constituents. 


\subsection{WELL POINT INSTALLATION TASKS}

\section{$2.1 \quad$ SITE CONDITIONS}

A water table contour map for the alluvial aquifer at the New Rifle site (Figure $2.1)$ indicates that ground water flows southwest in the area of the former tailings pile (the general area encompassed by this study) and that ground water surface elevations are near 5260 feet (ft) (1620 meters [m]) above sea level. Ground water at the New Rifle site in the alluvial aquifer flows southwest at a rate of approximately $300 \mathrm{ft}(90 \mathrm{~m})$ per year. Alluvial material in this area has been excavated to near the water table during surface remediation. Native alluvium, into which well points will be driven, consists of medium to fine sand, silt, gravels, and cobbles. A high percentage of cobbles are present in remaining native alluvial material. Usually, the percentage of cobbles increases abruptly near the water table. The underlying, semiconfined Wasatch Formation is usually encountered between 10 to $30 \mathrm{ft}(3$ to $9 \mathrm{~m})$ below the former land surface. The site is currently being backfilled with clean fill material. A final grading plan for surface remediation at the site (included as Attachment 3 to this report) shows that final ground elevations range from near $5270 \mathrm{ft}$ $(1620 \mathrm{~m})$ above sea level north of the former tailings pile to near $5260 \mathrm{ft}$ $(1620 \mathrm{~m})$ above sea level south of the former tailings pile. The depth to the water table when backfilling is complete is anticipated to be within 5 to $10 \mathrm{ft}$ ( 2 to $3 \mathrm{~m}$ ) of land surface in most of the area of investigation. Depths to ground water north of the pile near Highway 6 may be greater than $15 \mathrm{ft}(4.6 \mathrm{~m})$.

Redox conditions in the alluvial aquifer are generally oxidizing 1350 to 450 millivolts [mV]l and dissolved oxygen is commonly in the 0.5 to 2 milligrams per liter range, indicating that conditions are favorable for the aerobic biodegradation of organic constituents.

\subsection{WELL POINT LOCATIONS}

Four well point locations have been selected that have high probability of organic contamination (Figure 2.2). These locations include one in a former depression in Area 4 (an area where MK-Ferguson has identified organic material in soils) (well point RFN-01-0656), one location just downgradient of the former positions of a series of storage tanks possibly used to store organic liquids (well point RFN-01-0657), one location in the former gypsum pond area (well point RFN-01-0658), and one downgradient location within the footprint of the former tailings pile (well point RFN-01-0659). The latter two locations are in areas of the high recorded levels of inorganic contamination. Table 2.1 shows approximate northing and easting coordinates for each proposed well point. Several of these approximate well point locations may be adjusted slightly as a result of information obtained from recent MK-Ferguson soil sampling.

One well point (well point RFN-01-0655) will be installed upgradient from the former pile and from any potential contamination from the New Rifle site. This 


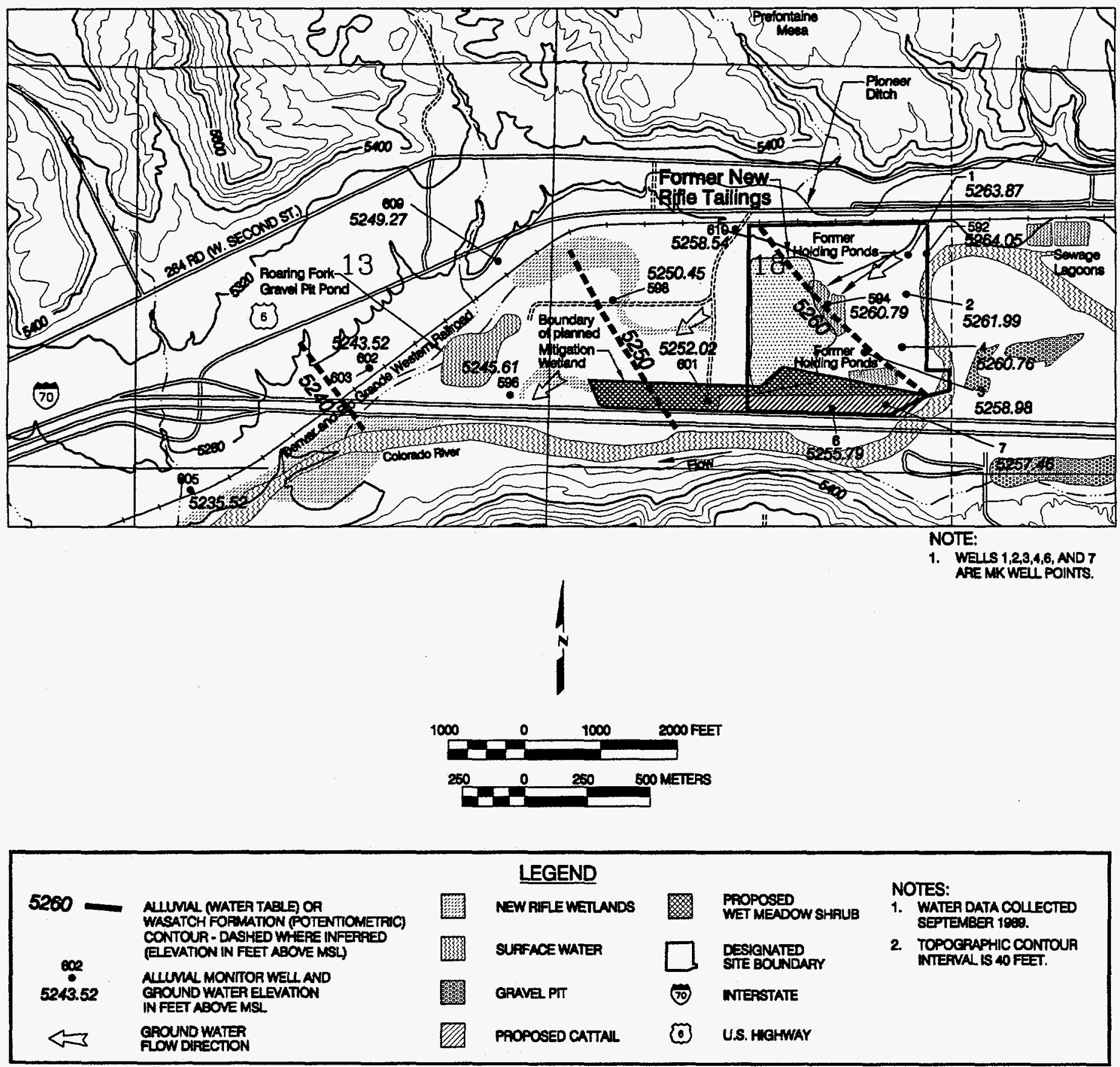

FIGURE 2.1

WATER TABLE CONTOUR MAP OF THE ALLUVIAL AQUIFER NEW RIFLE, COLORADO, PROCESSING SITE VICINITY 


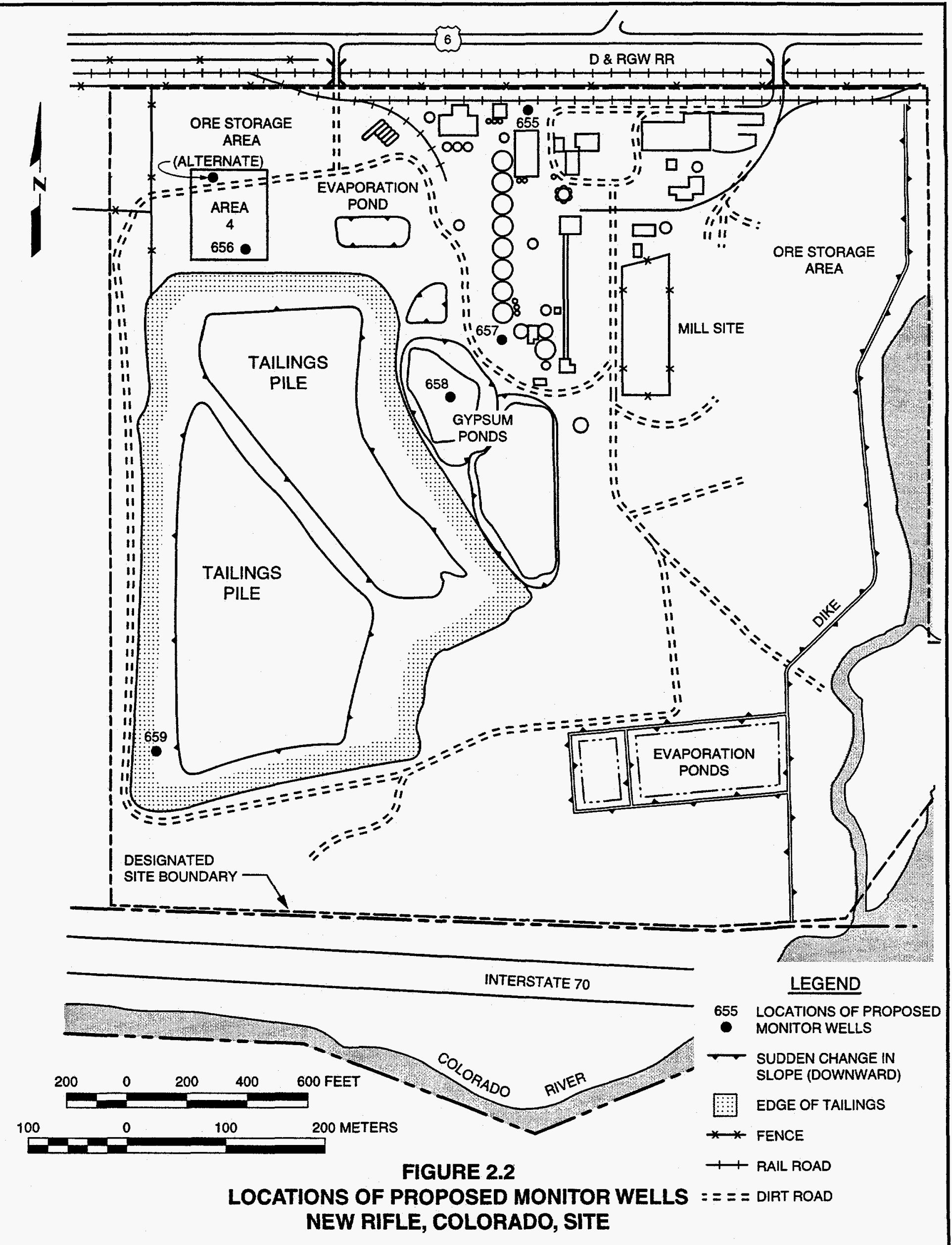


Table 2.1 Approximate northing and easting coordinates for proposed well points (based on MK-F construction coordinates)

\begin{tabular}{|c|c|c|c|}
\hline $\begin{array}{c}\text { Well point } \\
\text { number }\end{array}$ & $\begin{array}{l}\text { North } \\
\text { coordinate }\end{array}$ & $\begin{array}{c}\text { East } \\
\text { coordinate }\end{array}$ & Location/justification \\
\hline RFN-01-0655 & 25,500 & 48,000 & $\begin{array}{l}\text { Upgradient from any known potential site } \\
\text { contamination. }\end{array}$ \\
\hline RFN-01-0656 & 25,040 & 47,175 & $\begin{array}{l}\text { Depression in Area } 4 \text { (MK-Ferguson has } \\
\text { identified organic material in soils in Area 4). }\end{array}$ \\
\hline RFN-01-0657 & 24,775 & 47,850 & $\begin{array}{l}\text { Downgradient of the former positions of a series } \\
\text { of storage tanks. }\end{array}$ \\
\hline RFN-01-0658 & 24,550 & 47,675 & $\begin{array}{l}\text { Former gypsum pond area (highest recorded } \\
\text { levels of certain inorganic constituents). }\end{array}$ \\
\hline RFN-01-0659 & 23,550 & 46,875 & $\begin{array}{l}\text { Downgradient location within the footprint of } \\
\text { the former tailings pile (highest recorded levels } \\
\text { of certain inorganic constituents). }\end{array}$ \\
\hline (alternate) & 25,295 & 47.075 & $\begin{array}{l}\text { Depression in Area } 4 \text { (MK-Ferguson has } \\
\text { identified organic material in soils in Area 4). }\end{array}$ \\
\hline
\end{tabular}

well point will be located downgradient from an existing petroleum product tank farm.

An alternate location will be in Area 4 within the area of another former depression where MK-Ferguson has identified organic material in soils (Figure 2.2)

\subsection{PERMITS, CLEARANCES, AND ACCESS AGREEMENTS}

Proposed well points RFN-01-0655 through -0659 (Figure 2.2) will require access agreements prior to fieldwork. These new well points will also require well permits.

The Colorado Division of Water Resources will be contacted by the project regulatory specialist (PRS) for permitting information. The PRS and the site hydrogeologist will apply for and obtain any necessary permits. Property Management will obtain any needed access agreements before any fieldwork is initiated.

\subsection{WELL INSTALLATION METHODS}

Because of the heterogeneous nature of the aquifer materials and the presence of cobbles, a backhoe will be used to assist in well point installation at the site. Each shallow well will be approximately 10 to $15 \mathrm{ft}(3$ to $5 \mathrm{~m})$ deep and $(655$ may be 5 to $10 \mathrm{ft}[2$ to $3 \mathrm{~m}$ ] deeper than other wells) and consist of 
approximately $10 \mathrm{ft}(3 \mathrm{~m})$ of 2-inch (5-centimeter [cm])-diameter schedule 40 stainless steel well screen and approximately 2 to $8 \mathrm{ft}(1$ to $2 \mathrm{~m}$ ) of 4 -inch $(5-\mathrm{cm})$-diameter schedule 40 stainless steel casing. The wells will be screened such that screens straddle the seasonal high and low water table.

Well points will be installed by first excavating with a backhoe to the water table. During excavation a photoionization detector (PID) will be used to take field readings to qualitatively assess any organic levels. When the water table is reached, the casing and screen will be placed upright in the excavated pit and the point will then be driven further. The pit excavation will then be backfilled with cuttings to the original surface. Sand and bentonite may be added to the annulus as required.

A 5-ft $(2 \mathrm{~m})$-long steel protective casing will be installed over the well and a 4-inch $(10 \mathrm{~cm})$-thick concrete pad will be constructed around the base. A locking protective cap will be attached to the top of the casing.

Well construction materials will consist of the following:

- 2-inch $(5 \mathrm{~cm})$ stainless steel casing.

- 2 -inch $(5 \mathrm{~cm})$ stainless steel screen $(0.010$ slot) with stainless steel points.

- 6-inch $(15 \mathrm{~cm})$ polvvinyl chloride (PVC) temporary casing.

- 2-inch $(5 \mathrm{~cm})$ carbon steel drive casing.

- Locking 6-inch $(15 \mathrm{~cm})$ protective steel casing.

- Silica sand.

- Cement grout.

- Concrete.

- Bentonite chips.

- Rubber caps.

- Locks.

When applicable the following standard operating procedures (SOP) (JEG, n.d.) will be followed during well point installation:

\subsubsection{Instructions for Field Technical Representative (FTR)}

14.1.3 Drilling and Test Pit Technical Representative

14.1.4 Verification of Grout Mix for Monitor Wells

14.1.5 FTR Daily Diary

14.1.6 Procedures for Completing the Daily Field Activity Report

14.1.7 Field/Off-Site Procurement of Supplies \& Services

14.4.1 Soil and Rock Core Borehole and Test Pit Logging 


\subsubsection{Preparation of Logs for UMTRAP (UMTRA Project) Documents}

\subsubsection{Monitor Well Installation}

\subsubsection{Well Development}

16.1.19 Permitting Procedures for Installation or Decommissioning of Monitor Wells

16.1.22 Controlled Disposal of Potentially Contaminated Materials or memorandum from Don Metzler to Clinton Smythe entitled "Evaluating Drill Cuttings and Well Development and Purge Waters"

17.4.1 Location ID for Test Borings, Test Pits, and Monitoring Locations

Internal communications will be maintained among the field representatives, site hydrogeologists, the TAC Contracts Department, Property Management, the site manager, and the DOE. Before any wells are installed, the Remedial Action Contractor (RAC) site manager will be notified of the upcoming activities, and the work party will check in with the RAC. Any problems or complications encountered during fieldwork will be reported to the TAC site manager, who will forward the information to the DOE.

\subsection{WELL DEVELOPMENT}

No sooner than 48 hours after new well point completion, the well will be developed until the discharge is clear. The amount of water removed and approximate well yields will be recorded. An assessment of development water will be performed in the field as described in the Technical Approach for the Management of UMTRA Ground Water Investigation-Derived Wastes (DOE, 1994). Development water will be stored in 55-gallon (210-liter) drums at the New Rifle site, if determined necessary. If development water must be containerized, provisions will be made to properly dispose of the water.

Following development, at the well will be purged until turbidity is at an acceptable range.

\subsection{SURVEYING}

Before installation, surveying techniques will be used to accurately place the proposed well point locations relative to former positions of features that have been removed by surface remediation. After installation, the new well points will be surveyed by a local surveying contractor to establish top-of-casing elevation and final Colorado state plane coordinates. 
The TAC field staff will collect filtered samples from each new well point for the organic chemical assessment. In addition, quality assurance samples will consist of one field blank, one equipment blank, one trip blank, and one duplicate. The duplicate sample will be collected at location RFN-01-0659.

\section{Sampling protocol}

Sample collection will proceed one week after all of the newly installed ground water well points have been properly developed. Because these wells are constructed of stainless steel and will be screened across the water table, representative samples can be obtained without purging. Therefore, wells will not be purged before sampling, thus insuring the maximum possibility of detecting any organic contamination that might be present. An effort will be made to minimize drawdown during sampling to prevent water from cascading down the sides of the well screen during recharge, thereby minimizing loss of volatile organic constituents.

Disposable plastic bailers will be on hand at the site. Either the bailers or a peristaltic pump may be used for sampling for organic compounds. The pump and associated equipment will be decontaminated according to standard UMTRA protocols; these procedures conform to U.S. Environmental Protection Agency (EPA) guidance governing decontamination of equipment intended for use for sampling organic compounds in ground water. After sampling for organic constituents, samples will be taken for inorganic constituents using a peristaltic pump.

The organic samples will be placed with zero headspace in laboratory-supplied containers (see Attachment 4), placed on ice to preserve temperature less than 4 degrees Celsius, and shipped under strict chain of custody to the contract laboratory for analysis. Holding times are specified in the laboratory contract.

\section{Analysis}

Samples will be subjected to multiple analyses to learn as much as possible about their composition.

1. All samples will be screened by EPA gas chromatography (GC) Method 8015, modified for diesel-range organics.

2. All samples will be further analyzed for ammonium, arsenic, calcium, chloride, fluoride, iron, magnesium, molybdenum, nitrate, sodium, sulfate, uranium and vanadium to determine key inorganic characteristics in the shallow ground water in order to resolve relationships between inorganic and organic contaminants. 
3. All samples will be analyzed by EPA GC/mass spectrometry (MS) Methods 8260 (volatile compounds) and 8270 (semivolatile compounds) plus a routine extra peak (nontarget compound) report.

4. The analyses listed above will be performed by a commercial laboratory under contract to Jacobs Engineering Group Inc.

5. In parallel, splits of all samples will be sent to the RUST-Geotech Laboratory at the Grand Junction Projects Office compound. The chemists there will use their extensive analytical chemistry capabilities to attempt identification and quantification of process-related organics compounds, specifically those not on the target list for the EPA methods listed above.

\section{Quality assurance samples}

Quality assurance samples will consist of one field blank, one equipment blank, one trip blank, and one duplicate. The duplicate sample will be collected at location RFN-01-0659. One trip blank will be carried and analyzed by method 8260 for volatile compounds.

\subsection{SITE RESTORATION}

Pits that are excavated by backhoe will be restored to their approximate original contours, and only moderate site disturbance is anticipated. However, areas of disturbed soil will be raked smooth by hand; all trash will be collected and disposed of properly. Established roadways and paths will be used whenever possible.

Immediately following well installation and development, any contaminated water will be properly disposed of. All drums will be removed from the site.

\subsection{FIELD DOCUMENTATION}

In addition to the daily diary kept by the FTR, the following documentation will be compiled and data collected:

- The well point locations will be photographed and located on a map.

- The elevations of the top of casing for each well and the ground surface and northing and easting coordinates will be surveyed by the surveying subcontractor.

- Water sampling field forms will be completed, recording the following field parameters for ground water at the processing site: 
Static water level Dissolved oxygen Specific conductivity
Total depth of well Oxidation-reduction potential Turbidity
Alkalinity

pH

Temperature

Copies of all pertinent field documentation will be maintained in the UMTRA Project Document Control Center.

\subsection{ANTI-CONTAMINATION MEASURES}

Prior to the beginning of well installation procedures, an area free of contamination will be selected as the cleaning and staging area. All screen and casing materials to be used in constructing the well points will be steam cleaned and thoroughly scrubbed using an Alconox solution prior to installation. Before taking the backhoe onto the site, the backhoe bucket, arm, and controls will be cleaned as required. The FTR will inspect the backhoe for the presence of hydraulic oil or grease and all equipment will be steam cleaned to remove such material before each hole is dug. Proposed well points are in areas of suspected low-level ground water contamination. Therefore, to ensure that cross contamination does not occur, wells that are least likely to show organic contamination will be installed first. The backhoe arm and bucket will be steam cleaned between well sites and after the last pit has been completed. 
$=$ 


\subsection{HEALTH AND SAFETY}

\section{1 : SITE-SPECIFIC HEALTH AND SAFETY MEASURES}

Prior to excavation at each site, a safe area will be identified by barricading (with tape), the swing radius of the backhoe. The backhoe will be kept 2 to $4 \mathrm{ft}$ $(1 \mathrm{~m})$ away from the trench at all times. The excavated alluvial material will be kept on one side of the hole and a minimum of $2 \mathrm{ft}(1 \mathrm{~m})$ away from the excavation. All individuals involved with the work will stand beyond the pile of excavated material. No planks or bridges will be constructed across the excavated zone. Any ropes used during the installation will be loosely held by individuals to avoid their being pulled into the excavated zone. Ropes will not be left on the ground in a way that would increase the possibility of a worker's being caught by the rope. No one will enter the excavated area until it approximates land surface elevation.

The excavation will be monitored for organic fumes with a PID. If fumes are detected, all individuals with potential to be exposed will don respirators and Tyvek ${ }^{\text {mw }}$ protective clothing for further work. Respirators will be of the airpurifying half-mask type with organic cartridges. Individuals will be fit-tested before respirator use.

The attached "Hazard Review and Worker Safety Supplement for the Rifle Site" will be reviewed prior to conducting any fieldwork. All personnel involved with well point installation will have the following equipment:

- Hard hat.

- Steel-toed boots.

- Safety glasses.

- Work gloves.

- Sunblock lotion.

- Fresh drinking water.

- Respirator.

- Tyvek" protective clothing.

The following items will be on the site:

- First-aid kit.

- Fire extinguisher.

- Cellular telephone.

- PID.

The location of the nearest hospital in case of emergency is Clagett Memorial Hospital (303-625-1510) located at 701 E. 5th Street, Rifle, Colorado. A map showing the route to the hospital from the site is included in the attached 
"Hazard Review and Worker Safety Supplement for the Rifle Site." The phone number for all emergencies is 911 .

\section{2 - HEALTH AND SAFETY AUDITS}

The time on-site to complete well installation is likely to be less than 3 days, and it is not anticipated that an audit will be required. However, the FTR will be responsible for observing that individuals involved in work activities are in compliance with UMTRA Project health and safety requirements and that Occupational Safety and Health Administration codes 29 CFR Parts 1910 and 1926 are followed during all phases of well installation. The applicable SOPS (JEG, n.d.) are as follows:

\subsubsection{Occupational Safety and Health Complaints}

7.3.2 Occupational Safety and Health Complaints for TAC Subcontractors

14.1.2 Instructions for FTR 


\subsection{WELL INSTALLATION TASK SCHEDULE}

Well installation will follow placement of clean backfill at the New Rifle processing site. Placement of backfill could continue until January, thereby delaying completion of tasks included in this schedule. Therefore, the following schedule reflects the earliest possible date for the completion of each task.

The tasks and accompanying tentative completion dates for this work plan are as follows:

Task

Site visit

Equipment procurement

Well permits

Access agreements

Conduct field operation readiness

evaluation

Install wells

Survey wells

Sample wells
Completion

November 15

December 15

January 3

January 3

January 9

January 22

January 22

January 29 


\subsection{LIST OF CONTRIBUTORS}

The following individuals contributed to the preparation of this report.

\begin{tabular}{ll}
\hline Name & Contribution \\
\hline D. Erskine & Document coordinator \\
D. Erskine, T. Monks, B. Toth & Primary authors \\
S. Cox, A Holm & Document review \\
J. Jones & Editing \\
K. DeGruyter, S. Suniga & Graphics \\
L. Sanchez & Text processing \\
\hline
\end{tabular}




\subsection{REFERENCES}

AlHAAP, 1962. American Industrial Hygiene Association Journal, Vol. 23, p. 95.

Casarett L. J., and J. Doull, 1991. Toxicology: The Basic Science of Poisons, fourth edition, M. O. Amdur, J. Doull, and C. D. Klaassen, eds., Pergamon Press, New York, New York.

DOE (U.S. Department of Energy), 1994. Technical Approach for the Management of UMTRA Ground Water Investigation-Derived Wastes, DOE/AL/62350-109, prepared by the U.S. Department of Energy, UMTRA Project Office, Albuquerque, New Mexico.

Eder et al., 1979. Preparations for defoliation; GER. OFFEN. PATENT 2914164, 25 October 1979, (SANDOZ-PATENT-GMBH).

EPA (U.S. Environmental Protection Agency), 1989. Two Generation Range Finding Study of Tributyl Phosphate Administered in the Feed to CD (Sprague-Dawley) Rats, EPA/OTS, Doc. No. 89-910000143, U.S. Environmental Protection Agency.

EPA (U.S. Environmental Protection Agency), 1980. Chemical Hazard Information Profiles (CHIPs), TSCA Chemical Assessment Series, August 1976 - August 1978, pp. 176-182 and 269-282.

Farquhar, T., 1995. Morrison Knudsen-Ferguson, personal communication to S. Arp, U.S. Department of Energy, UPDCC File Location No. 6.19.4.6, Albuquerque, New Mexico, 2 November 1995.

Gerhart et al. (J. M. Gerhart, R. W. Tyl, C. B. Myers, M. C. Marr, D. R. Brine, J. C. Seely), 1993. "Two Generation Study of Dietary Tributyl Phosphate (TBP) in CD Rats," Toxicologist, Vol. 13, No. 1, p. 76

HYDRA, 1978. Hydrometallurgy, Vol. 3, p. 201.

JEG (Jacobs Engineering Group Inc.), n.d. Albuquerque Operations Manual, standard operating procedures, prepared by Jacobs Engineering Group Inc., Albuquerque, New Mexico, for the U.S. Department of Energy, UMTRA Project Office, Albuquerque Operations Office, Albuquerque, New Mexico.

Laham et al. (S. Laham, B. Broxup, G. Longl, 1985. "Induction of Urinary Bladder Hyperplasia in Sprague-Dawley Rats Orally Administered Tri-n-butyl Phosphate," Arch. Environ. Health, Vol. 40, pp. 301-306.

Laham et al. (S. Laham, G. Long, B. Broxup), 1984. "Subacute Oral Toxicity of Tri-n-butyl Phosphate in the Sprague-Dawley Rat," J. Appl. Toxicol., Vol. 4, pp. 150-154. 
Laham et al. (S. Laham, J. Szabo, G. Long), 1983. "Effects of Tri-n-butyl Phosphate on the Peripheral Nervous System of the Sprague-Dawley Rat," Drug Chem. Toxicol., Vol. 6. pp. 363-377.

Meritt R. C., 1971. The Extractive Metallurgy of Uranium, Colorado School of Mines Research Institute, Golden, Colorado.

Proctor et al. (N. H. Proctor, J. P. Hughes, M. L. Fischman), 1988. Chemical Hazards of the Workplace, second edition, SIRS, pp. 484-485.

Sabine, J. C., and F. N. Hayes, 1952. "Anticholinestarase Activity of Tributyl Phosphate," Archives of Industrial Hygiene and Occupational Medicine, Vol. 6, pp. 174-177.

\section{CODE OF FEDERAL REGULATIONS}

29 CFR Part 1910, Occupational Safety and Health Standards, Occupational Safety and Health Administration, U.S. Department of Labor.

29 CFR Part 1926, Safety and Health Regulations for Construction, Occupational Safety and Health Administration, U.S. Department of Labor.

40 CFR Part 192, Health and Environmental Protection Standards for Uranium and Thorium Mill Tailings, U.S. Environmental Protection Agency.

40 CFR Part 264, Standards for Owners and Operators of Hazardous Waste Treatment, Storage, and Disposal Facilities, U.S. Environmental Protection Agency. 
TAILINGS

Conc. MDL $\mathrm{U}_{\mathrm{g}} / \mathrm{Kg} \quad \mathrm{U}_{\mathrm{g}} / \mathrm{K}_{\mathrm{g}}$
LKV

RFN Acetone

Acrylonitrile

Benzene

2, 4-D

$2,4,5-T$

$2,4,5-T P$

Carbon disulfide

Chloroform

Di-n-octylphthalate

Methyl bromide

Methyl chloride

Methyl ethyl ketone

Trichlorofluoromethane

Toluene

Xylene

$\begin{array}{lr}\text { nd } & 330 \\ 220-410 j & 330 \\ \text { nd } & 5 \\ 44 & 40 \\ \text { ne } & \\ & \\ \text { nd } & 10 \\ 6 \mathbf{j} & 100 \\ 3 j & 5 \\ 410 & 200 \\ \text { nd } & 160 \\ 62 & 40 \\ \text { nd } & 5 \\ 3 j & 5 \\ \text { nd } & 330 \\ 7 j & 10 \\ \text { nd } & 5 \\ \text { nd } & 10 \\ \text { nd } & 5 \\ \text { nd } & 5 \\ \text { nd } & 5\end{array}$

$7 \mathrm{j} \quad 10$

$19 j-15 j \quad 100$

nd

$130 j$

$3 j-5$

770

1000

$250 j$

1400

520

$180 \mathrm{j}$

990

830

$4 j$

$4 j$

630

na

ne
GROUNDWATER

Conc. $\mathrm{MDL}$

$U_{g} / L \quad U_{B} / L$ 


\section{ATTACHMENT 1}

RESULTS OF 1989 APPENDIX IX SCREENING 
5301 CENTRAL AVENUE N.E. - SUITE 1700. ALBUQUERQUE, NEW MEXICO 87108

TELEPHONE (505) $046-4030$

November 8, 1989

DOCUMENT CONTROL

Mr. Mark Matthews

Acting UMTRA Project Manager

U.S. Department of Energy

Uranium Mill Tailings Project Office

5301 Central Avenue, N.E., Suite 1720

Albuquerque, New Mexico 87108

Attention: Steve Hamp

Re: Results of Appendix IX Screening Contract No. DE-ACO482-AL14086

Dear Mark:

Enclosed are the findings of the Appendix IX Special Study. The object of this effort was to screen twe lve UMTRA Project sites for the organic constituents listed in 40 CFR 264 Appendix IX. The sites screened were Ambrosia Lake, Durango, Grand Junction, Green River, Gunnison, Lakeview, Mexican Hat, Monument Valley, Old and New Rifle, Spook and Tuba City. This screening effort evaluated both tailings and groundwater samples, where available. While a number, of sites showed detectable concentrations: of hazardous constituents, onfy-the Rifie site shows concentrations sufficiently high to requte further characterization. The further characterization will be conducted using site-specific funds.

This submittal concludes the work on the Appendix IX Special Study. If you have any questions, please contact Frank Titus or me.

Very truly yours,

JACOBS ENGINEERING GROUP INC.

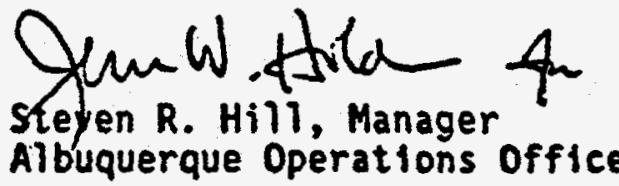

SRH/FT/BD/II

Enclosure

cc: KAgogino

KBostick

SHill

DLechel

BMukhopadhyay 
UPDATE ON THE RESULTS OF SCREENING THE HAZARDOUS ORGANIC CONSTITUENTS IN THE TAILINGS AND GROUNDWATERS OF THE UMTRA TITLE I SITES

The results of screening for the hazardous organic constituents listed in Appendix IX, 40 CFR 264 and (consistent with those listed in the draft-final version of Appendix I, 40 CFR 192) in the tailings and groundwaters at the UMTRA processing sites currently completed, are shown in Table 1.

The organic compounds in Table 1 include those that appear to be present but are below the laboratory method detection limit (MDL). (footnote " $g$ " in Table 1, and those that were also detected in laboratory blanks: footnote " $b$ "). This table also contains, a) phthalates that are common organic contaminants, and b) common laboratory reagents methyl chloride and methy? lodide with concentration levels at or near the (MDL). These compounds should be dropped from further consideration. Table 2 contains only those compounds that need further evaluation for their potential presence as groundwater contaminants at the UMTRA sites. Where more than one sample was analyzed, Table 2 shows the maximum observed concentration of a constituent present in either or both tailings and groundwaters beneath and downgradient from the tailings.

Table 2 shows that a groundwater sample from HAT contains lindane (an insecticide). It's concentration $(.18 \mathrm{ug} / 1)$ however, is below the EPA MCL for lindane $(4 \mathrm{ug} / 1)$ and therefore, does not require further consideration. Likewise, the alpha BHC (also an insecticide; lindane is gamma BHC) which appears to be present in the groundwater sample from beneath the old Rifle processing site, occurs at about the same concentration level as lindane but is less toxic, and therefore, can be eliminated from further consideration.

A small amount (3.6 times the MOL) of toluene appears present in the groundwater beneath the tailings pile of the New Rifle site (RFN). 'This RFN groundwater also appears to contain a trace (2.5 times the MDL) amount of 2, 4, 5-T (a defoliant). A systematic sampling and analysis of groundwater at this site needs to be carreforout in order to a) confirm a the presence- of -these compounds, and b) if present, define the size of the contamination pitumel (s)

A number of organic compounds at a concentration level up to about 4 times the MDL appears to be present in the tailings at a number of sites (Table 2). However, one AMB tailings sample contains toluene at a concentration level of 30 times the MDL and two HAT tailings samples contain acetone at concentration level set about 1000 times the MDL. None of these compounds is present in the groundwater for a given site. Therefore, it can be assumed that they are not available to, or are insoluble in, groundwaters beneath the tailings.

In sumary, anditional groundwater sampling and analyses should be

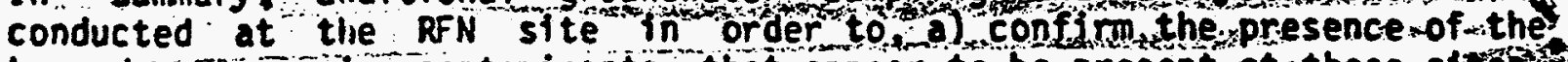
hazardous organic contaminants that appear to pe presentivatuthese sitest

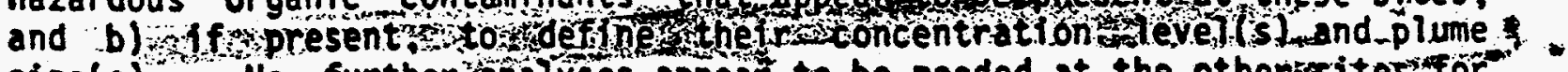

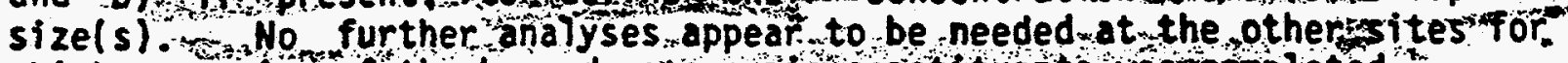
which screening of the hazardous organic constituerits was completed. 
a

iI.
WORK ORDER PLAN - CHEMICAL ANALYSIS OF UMTRA TAC SAMPLES

SAMPLE MATRIX: Ground Water

SITE HYDROLOGIST: TMonks

NAME (print)

SIGNATURE

DATE

SITE ID(s): RFN-01

SITE GEOCHEMIST: DErskine

NAME (print)

SIGNATURE

DATE

LOCATION ID(s): See Below

SAMPLES ID(S): $000 X$

\begin{tabular}{|c|c|c|c|c|c|c|c|c|c|c|c|c|c|c|c|c|c|}
\hline $\begin{array}{l}\text { Bottle } \\
\text { Name }\end{array}$ & $\mathrm{Cu}$ & $\mathrm{Fe}$ & $\mathrm{Pb}$ & Mn & $\mathrm{Hg}$ & Mo & $\mathrm{Ni}$ & Se & $\mathbf{A g}$ & Sr & Sn & $\mathrm{TI}$ & $u$ & $v$ & $2 n$ & TDS & $\begin{array}{c}\text { TOC \& } \\
\text { DOC }\end{array}$ \\
\hline$M-2$ & & $x$ & & & & $x$ & & & & & & & $x$ & $x$ & & & \\
\hline & & & & & & & & & & & & & & & & & \\
\hline & & & & & & & & & & & & & & & & & \\
\hline & & & & & & & & & & & & & & & & & \\
\hline & & & & & & & & & & & & & & & & & \\
\hline & & & & & & & & & & & & & & & & & \\
\hline $\begin{array}{l}\text { Total \# } \\
\text { of Tests }\end{array}$ & & 8 & & & & 8 & & & & & & & 8 & 8 & & & \\
\hline
\end{tabular}

COMMENTS:

Please analyze samples RFN01-655-0001, RFN01-656-0001, RFN01-657-0001, RFN01-658-0001, RFN01-659-0001, RFN01-659-0002, RFN01-999-0001, and RFN01-999-0003. 
TABLE 1 : SCREENING RESULTS OF THE EPA APPENDIX IX (40CFR264) HAZARDOUS OROANIC COMPOUNDS IN THE UMTRA

TITLE I SITES

TAILINGS

Site Compound

AMB

MethylEthylKetone

Acetone

Carbon disulfide

Methyl Chloride

Styrene

Toluene

Trichlorofluoromethane

Xylene(total)

DUR Pentachlorophenol

Trichlorofluoromethane

GRJ Toluene

Bis (2-Ethylhexyl) phthalate

GRN

Acetone

Bis (2-Ethylhexyl)

Toluene phthalate

GuN Diethylphthalate

Bi(2-ethylhexyl) phthalate

Trichlorofluoromethane

HAT
Conc.

$\mathbf{U}_{\mathbf{B}} / \mathbf{K}_{\mathbf{B}}$

nd

15

15

6

$14 \mathrm{~b}$

150

$62 \mathrm{~b}$

5

na

na

$3 \mathbf{j}-1 \mathbf{j}$

nd

$6-4 j$

nd

9

356

nd

$1.7 j$

$12000 \mathrm{e}$

$195-216$

nd

nd

440

$11-250$
Acetone

2, 4-D

Lindane

Methyl Iodide

Bis( 2-ethylhexyl)

phathalate
MDL $U_{8} / K_{B}$

10

10

5

5

5

5

5

6

na

ne

5

330

10

330

5

330

330

5

10
200
8
5

330

5
GROUNDWATER

Conc.

HDL

Ug/L

$U_{B} / L$

$$
\begin{aligned}
& \text { 7j } \\
& \text { nd } \\
& \text { nd } \\
& \text { nd } \\
& \text { nd } \\
& \text { nd } \\
& \text { nd } \\
& \text { nd }
\end{aligned}
$$

$7 \mathbf{j}$

$3 \mathbf{j}$

10

5

5

10

10

10

12-10

nd

5

10

nd

360-110 10

nd

5

10

10

.05

5

5

10 
TABLE 2 : POTENTIAL haZARDOUS ORGANIC CONSTITUENTS

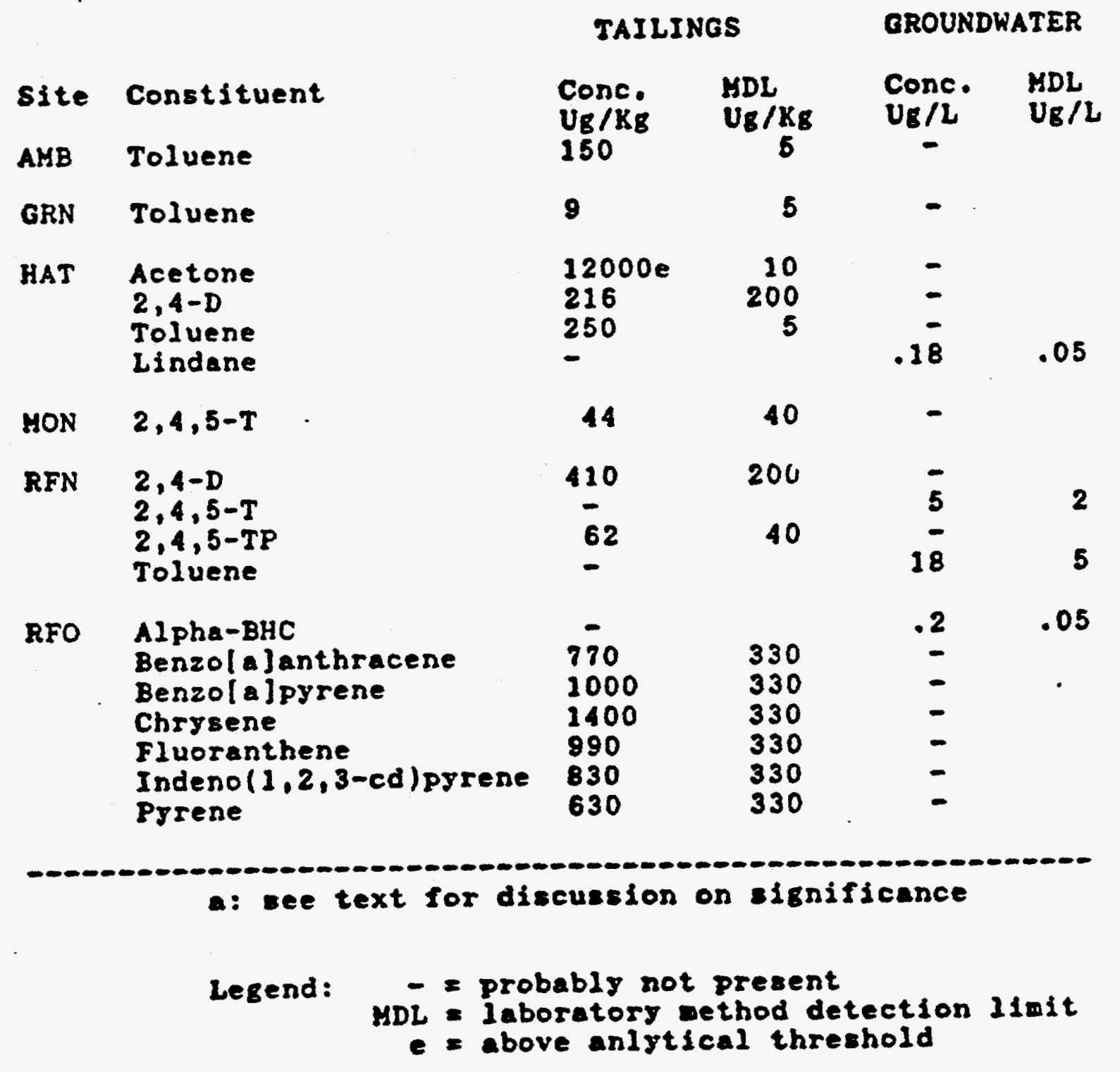


ATTACHMENT 2

MK-FERGUSON ORGANIC ANALYSIS 
DATE:

MK-FERGUSON COMPANY

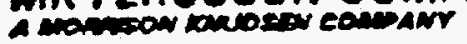

.

2195

TIME: $4: 05$

\section{$\square$ RUSHMeliver Immediately $\square$ Deliver ASAP}

PLEASE DELTVR THE FOLLOWING TO:

Nume: Sharon Arp

rRom: Teresu Farquhur

LOCATION:
FAX TO (PH. NUMBER):

LOCATION: ALBUQUERQUE, RM PROJECT OFFTCE

FAX USER (PH. NUMBER):

$505 / 766-3318$ or $505 / 766-1813$

TOTAL OF PAGES 15

EXCLUDING COVER SFEET)

IF YOU DO NOT RECEIVE ALI PAGES, CALL FAX USER AT 1-800-443-4379 or 505/845-5868

REMARKS:

Sharon

Cald John Isham \& myself

to discuss these results.

Tersea 


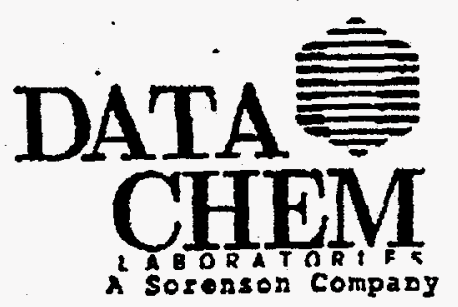

ANALYTICAL REPORT

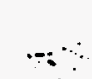

Form ARF-AL

Page 6 of 7

Part 6 of 6

\section{Date OCT 151995}

Agency Identification Number S95-1106-CE

Account No. 03018

MK-Ferguson Company

P.O. BOX 151

Rifle, co 81650

Attention: Kathy Benson

FAX (303) 625-4623

Telephone

Sampling Collection and Shipment

Sampling Site

Date of Collection Dctober 03,1995

Date Samples Received at Laboratory latober 04,1995

Analysis

Method of Analysis ERA B240

Date(s) of Analysis October 09, 1005

Aralytical Results

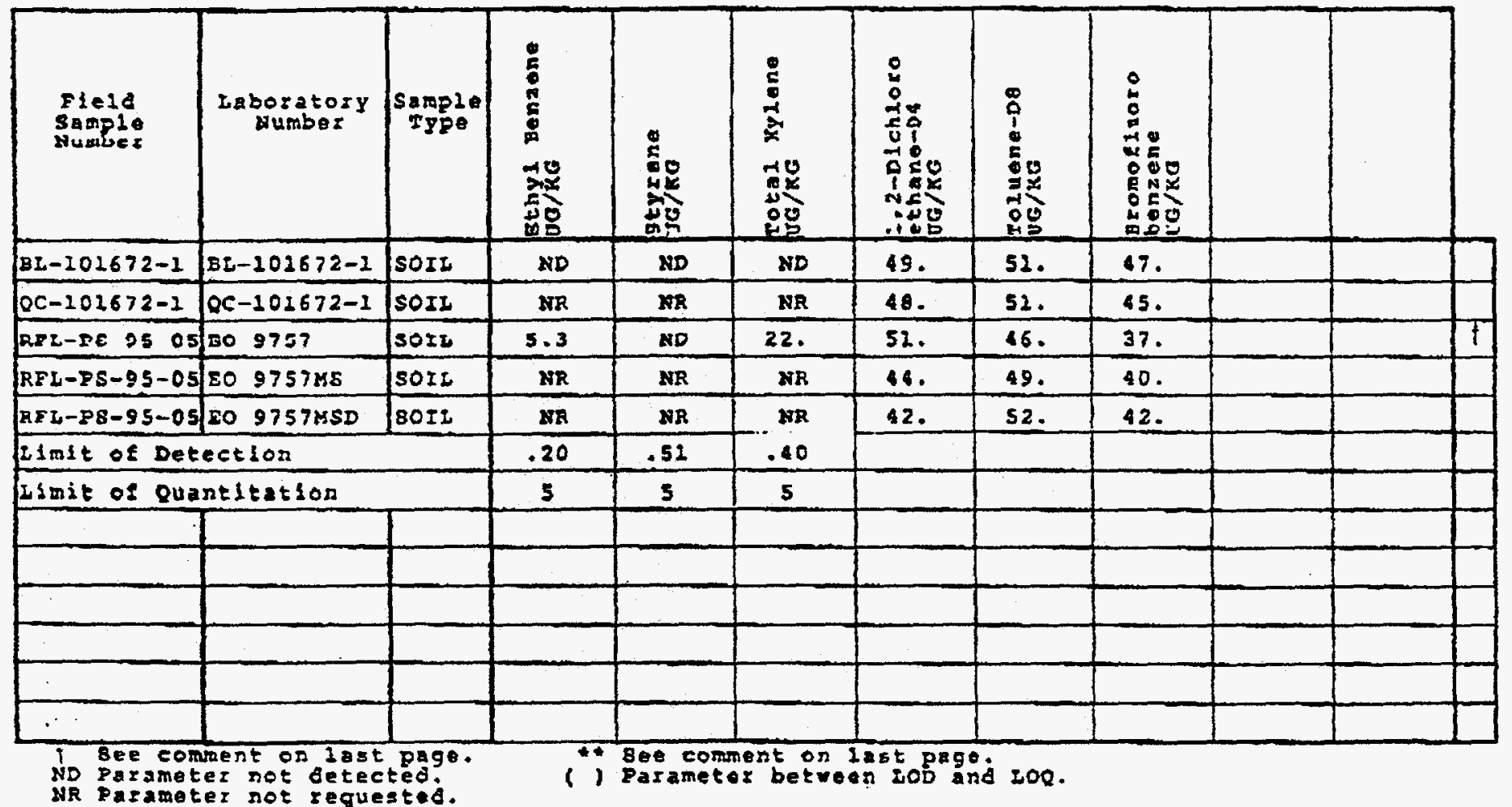




\section{$\varepsilon-Z \forall$}

${ }_{\infty}^{1334}$

\section{8 outsusus}

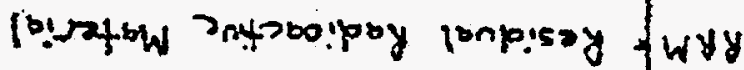

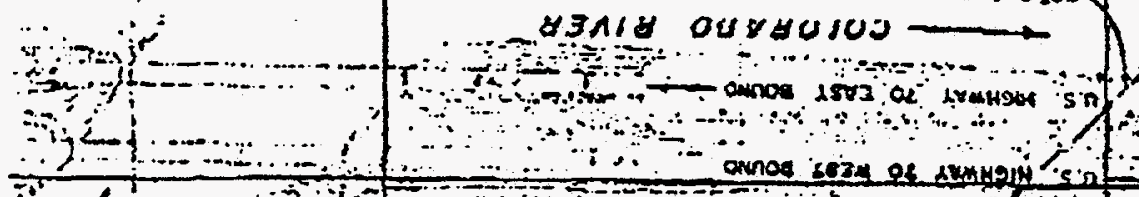

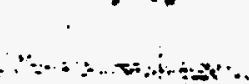

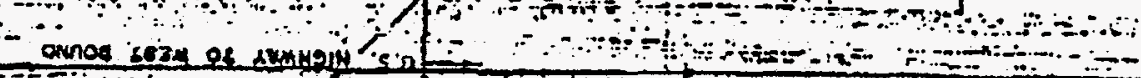

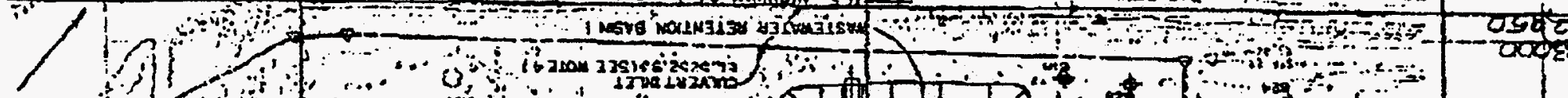

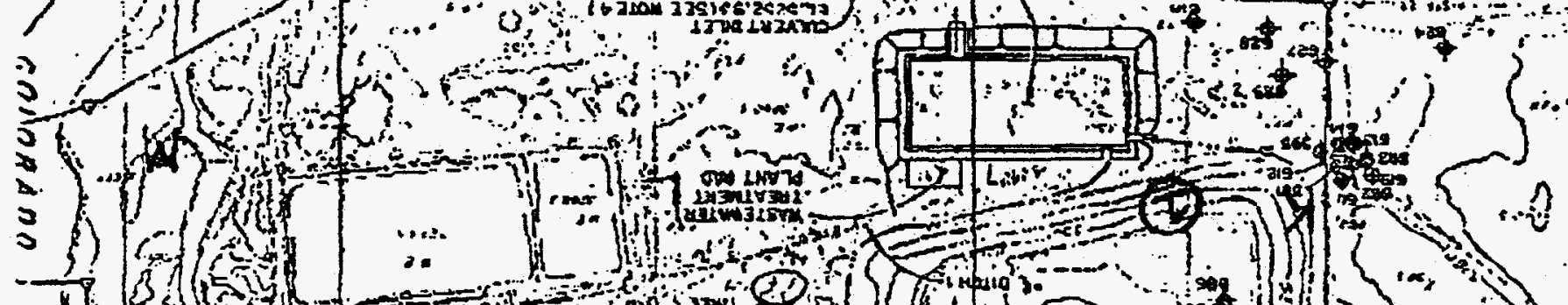

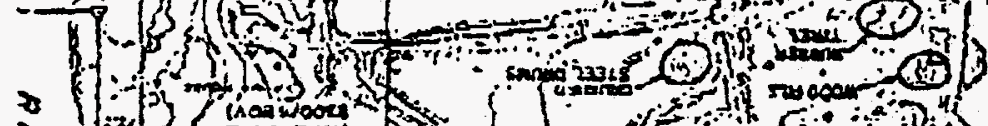

$\sum$

$\rightarrow$

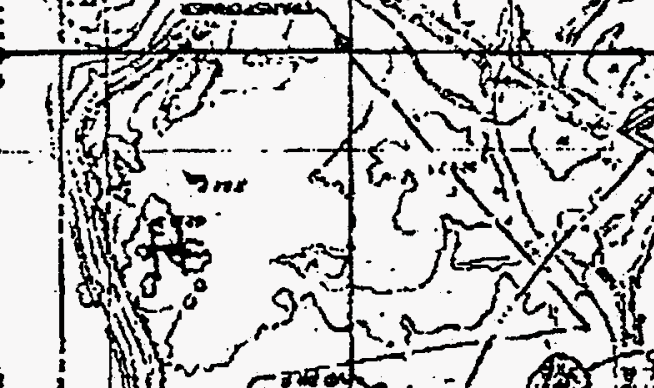

3

3.3 (3) /

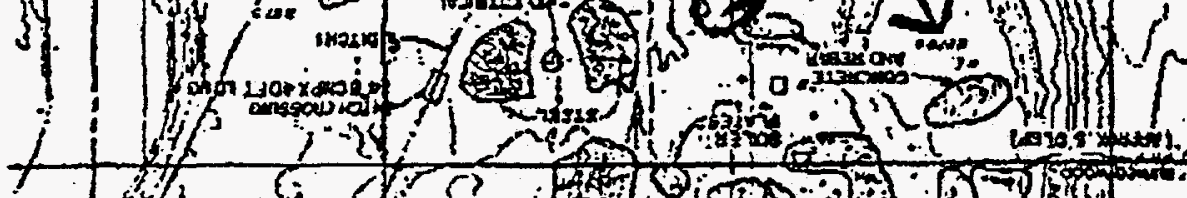
in
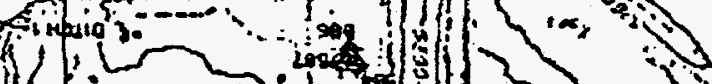

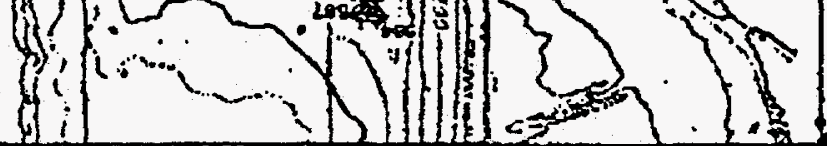
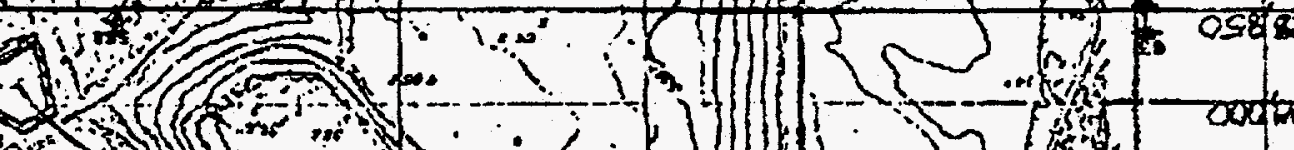

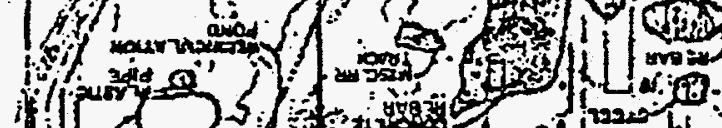

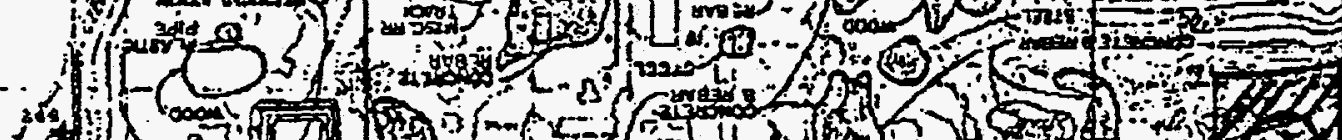

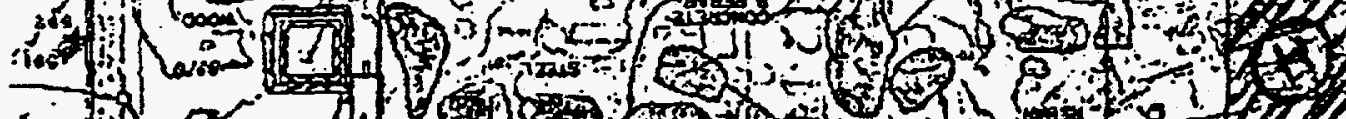

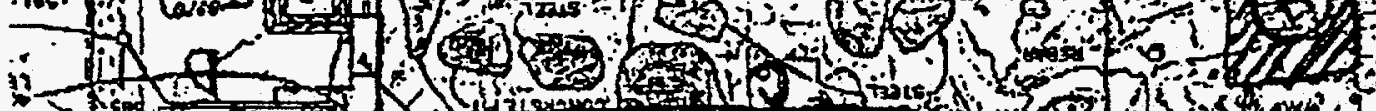
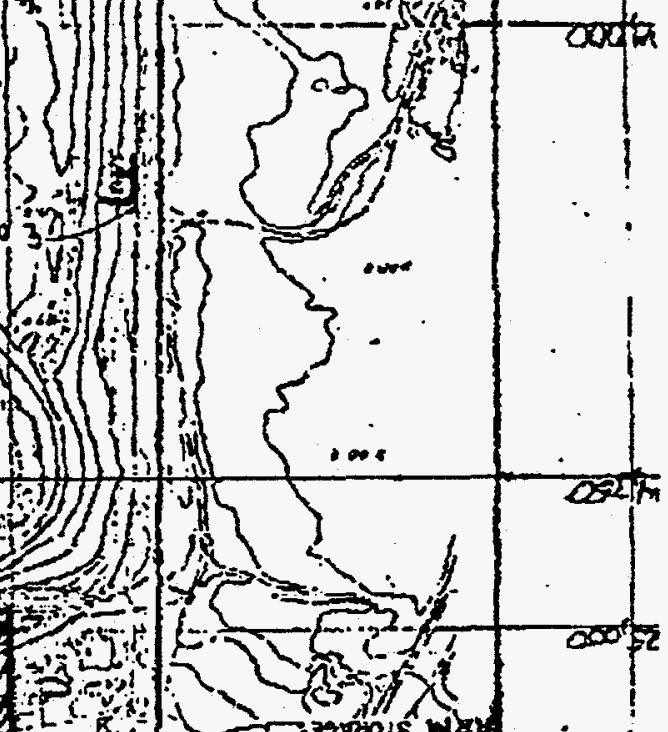

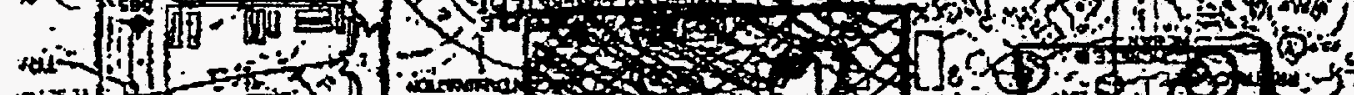

(7:-3)

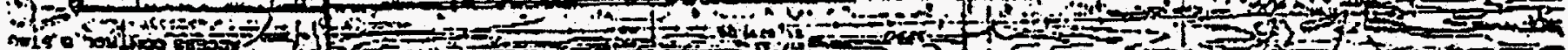

$\therefore 150$ on

:52

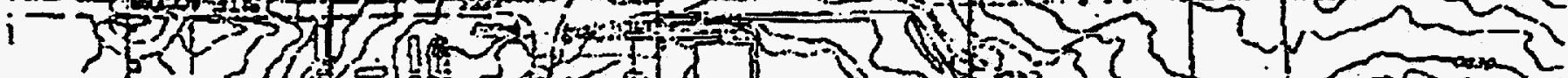

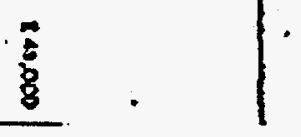

$20 \cdot d$ BTEEggLest

$20^{\circ} d \quad \exists 00$
8

a1.

01
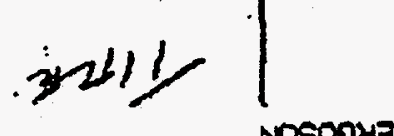

8

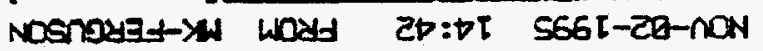

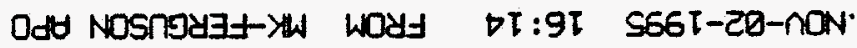




\section{NEW RIFLE PROCESS SITE SOIL SAMPLES}

\section{3-95}

Rifle UMTRA

$\begin{array}{lllll}\text { Map \# } & \text { Soil Sample \# } & \text { Area } & \text { Concern } & \text { Status } \\ 1 & \text { RFL-PS-93-1 and } 2 & \text { K } & \text { Organics } & \text { Soil removed } \\ 2 & \text { RFL-PS-1 through 6 } & \text { C } & \text { pH } & \text { Acid pond removed } \\ 3 & \text { RFL-PS-94-7 through 10 } & \text { G } & \text { Organics } & \text { Gyp pond removed } \\ 4 & \text { RFL-PS-95-1 through 3 } & \text { B } & \text { Organics } & \text { Rad cleaned only } \\ 5 & \text { RFL-PS-95-4 } & \text { G } & \text { Organics } & \text { Soil removed } \\ 6 & \text { RFL-PS-95-5 } & \text { G } & \begin{array}{l}\text { Organics, } \\ \text { Sulfates }\end{array} & \text { Rad cleaned only }\end{array}$

Note: The Area designation, "K," "C," "G," etc. are referring to radiological verification maps, not engineering excavation maps. 


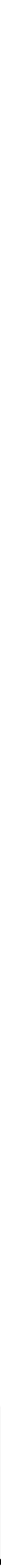




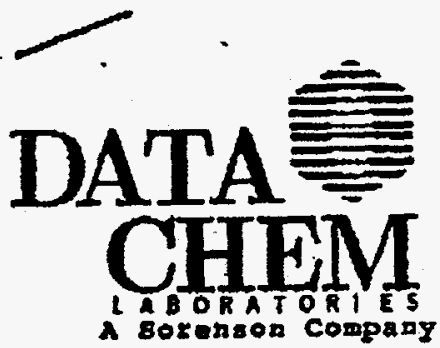

MX-Perguson Company

P. O. Box :151

Rifle, 00 i 650

Attention: Kathy Benson
ANALYTICAL REPORT FOTM ARF-AL

$\begin{array}{llll}\text { Page } & 1 & \text { of } & 2 \\ \text { Part } & 1 & \text { of } & 1\end{array}$

\section{Date SEP 252995}

Agency Identification Number $\mathrm{NO5}=0020-\mathrm{AB}$

Account No. 03020

Sampling Collection and Shipment

sampling site

Date of Collection August 30, 1995

Date Samples Recelved at Laboratory August 31, 1995

Analysis

Method of Analysis OC-DC-TPHD

Date(8) of Analysis September 15, 2995 - September 19, 1905

Analytioal Results

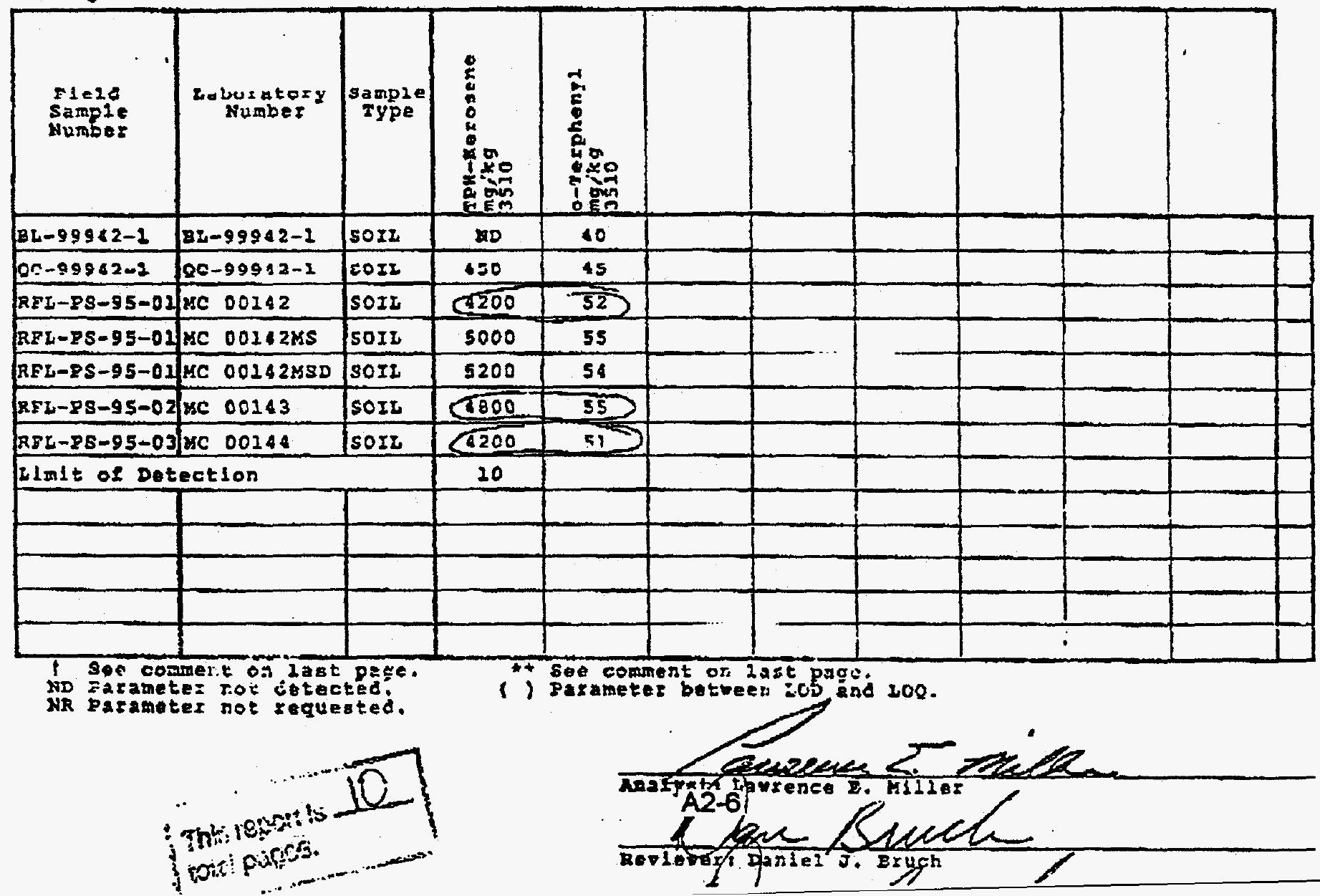




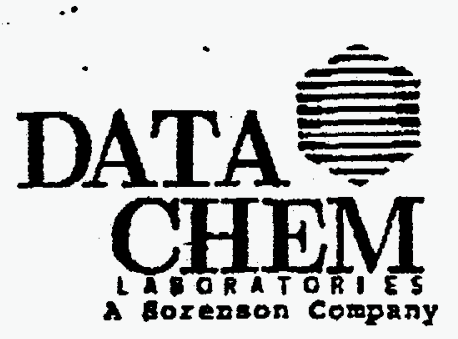

ANALYTICAL REPORT

Form ARF-C

Page 2 of 2

Date SEP 131995

Agency Identiflcation Number $995-0020=C B$

\section{General Set Comments}

Sample BL-100331-1 was analyzed as the method blank. Sample OC-100331-1 was analyzed as the laboratory control semple (LCS). Sample MC 00142 was used to prepare the matrix spike and matrix spike duplicate samples (MS and MSD). The LCS, MS, and MSD were splked at $400 \mathrm{ug} / \mathrm{kg}$ with benzene, toluene, and ethylbenzene, and at $1200 \mathrm{ug} / \mathrm{kg}$ with total xylene.

Reporled values have not been corrected for molsture content.

\section{Sample Comments}

Laboratory

Number

- Comment ..-

BL-100331-1

MC 00143

MC 00144

(J)

$(\mathrm{J})$ 
DATA CHEM
ENVIRONMENTAL SOIL REPORT Page 1 of 1

Part 1 of 1

Date OCT 161995

Agency Identification Number \$95-1106-DE

Account No. 03018

MK-Ferguson Company

P.0. BOX 151

Rifie. $\operatorname{co} 81650$

Attention: Kathy Benson

FAX (303) 625-4623 Telephone

Sampling Collection and Shipment

Sampling Site

Date of Collection Osivilutr. 03, 1995

Date Samples Received at Laboratory latober 04, 1995

Analytical Results

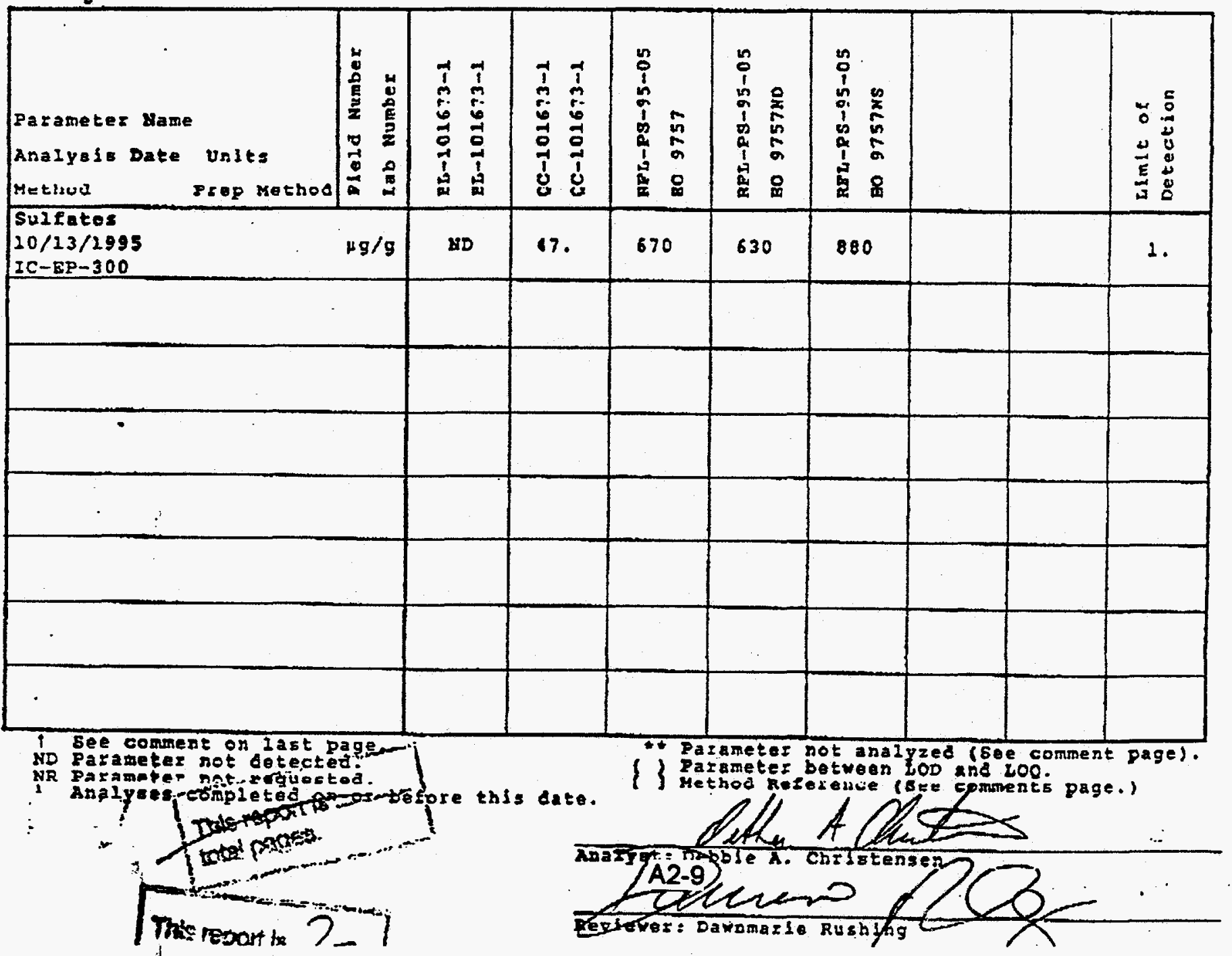


$\Leftrightarrow \quad \because \because \quad$

\section{DATA

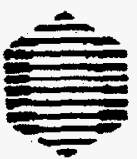 \\ ENVIRONMENTAL WATER REPORT \\ Form EPRH-A.}

Date OCT 104995

Agency Ident1fication Number SO5-1106-EE

Account No, 03018

MK-Eerguson Company

P.O. Box 151

Rifle, Co 81650

Attention: Kathy Benson

FAX (303) 625-4623

Telephone

Sampling Collection and Shipment

Sampling Site

Date of Collection Datober 03, 1995

Date Samples Recelved at Laboratory Oatober 04, 1995

Analytical Results

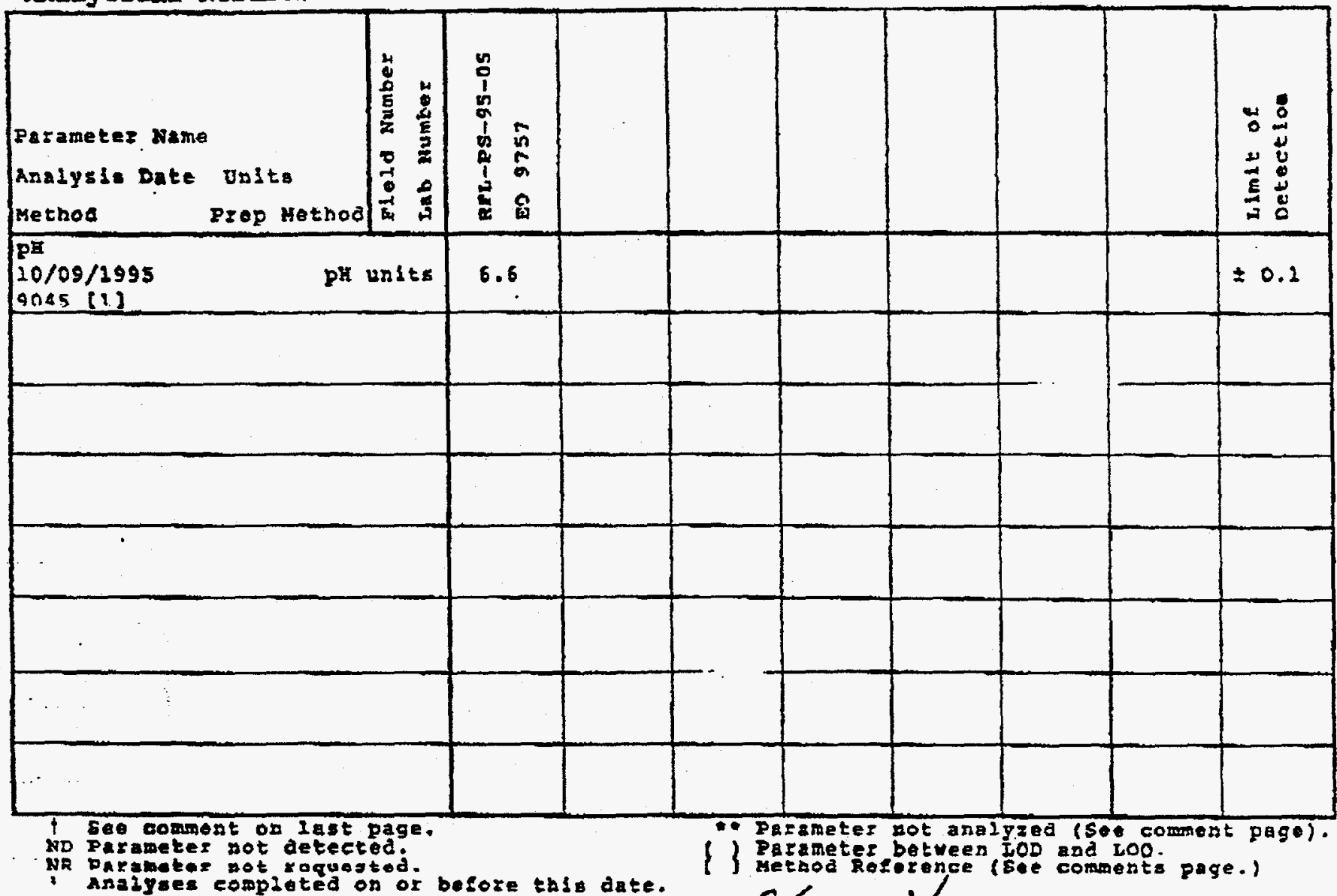

NR baxibeter pot raguastod

Metuod Reforence (E) comments page.

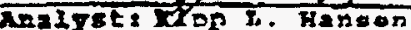

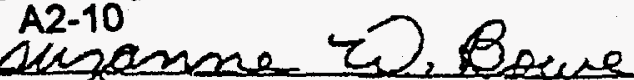




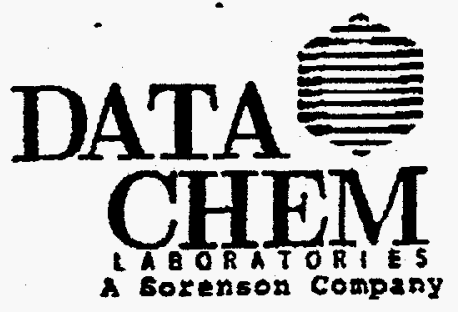

MK-Ferguson Company

P.O. Box 151

Rifle, Co 81650

Attention: Kathy Benson

\section{ANALYTICAL REPORT FOrm ARF-AL}

Page 1 of 7

Part 1 of 6

Date OCT 161995

Agency Identification Number $595-1206-C E$

Account No. 03018

Sampling Collection and Shipent

Sampling Site

Date of Collection Datober 03, 1095

Date Samples Received at Laboratory October 04, 1995

Analysis

Method of Analysis EPA 8240

Date (s) of Analysis Datober 09, 1095

Aralytical Results

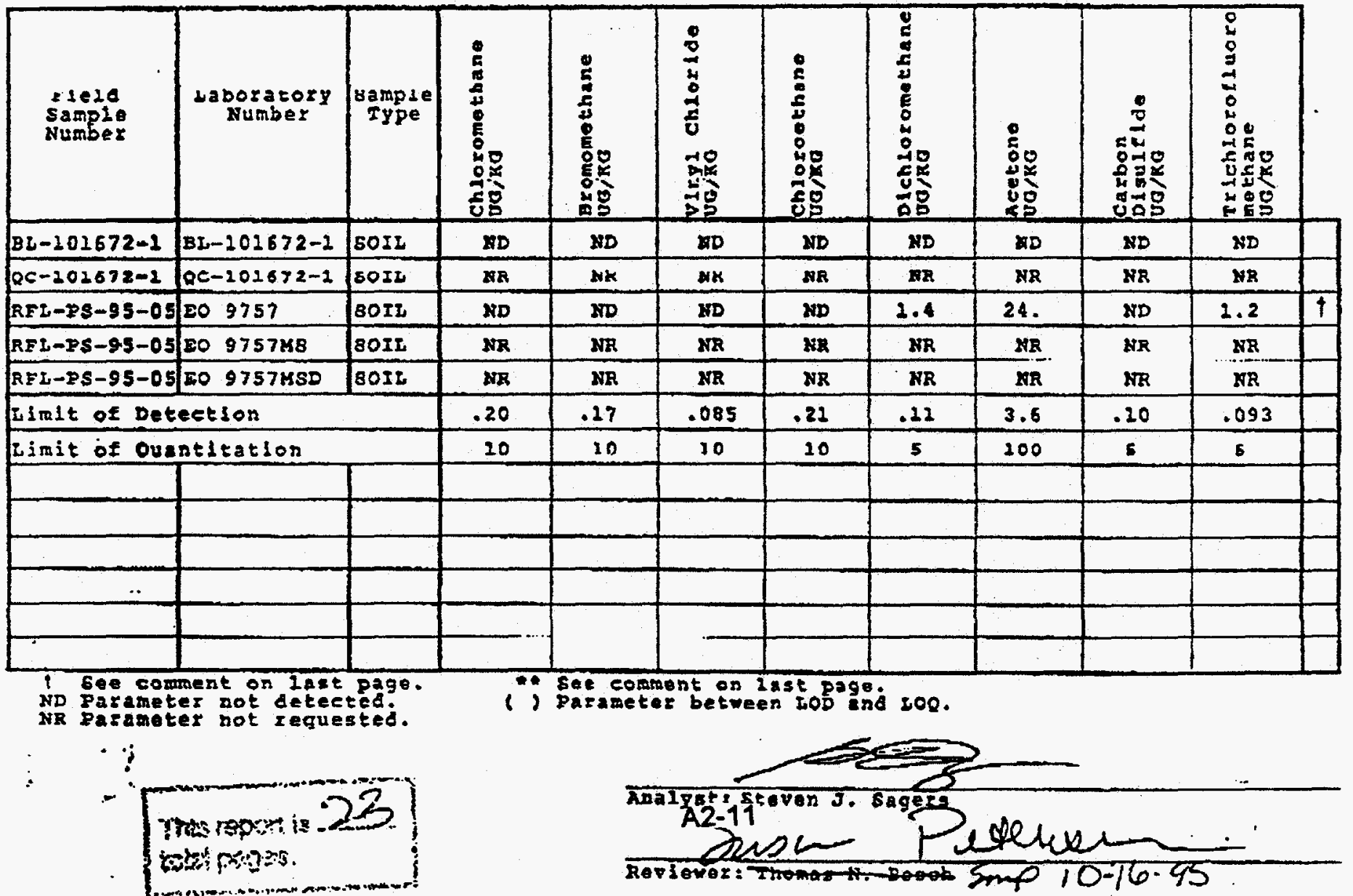




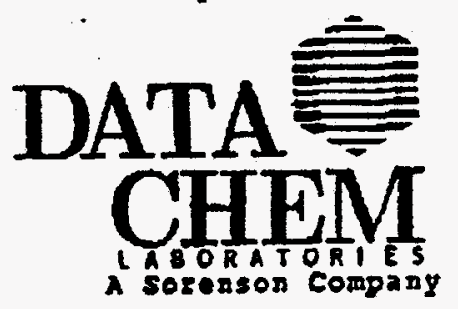

ANALYTICAL REPORT

Date
FOrD ARF-AL

Page 2 of 7

Part 2 of 6

\section{OCT 161995}

Agency Identification Number S05-1106-CE

Account No. 03018

MiK-Eerguson Company

P.O. Box 151

Rifie, $C 081650$

Attention: Kathy Benson
FAX (303), 25023

Telephone

Sampling collection and Shipment

Bampling Site

Date of Collection Detober 03, 1905

Date Samples Received at Laboratory ectober 04, 1095

Analysis

Method of Analysis ERA 8240

Date(s) of Analysis 0atober 09, 1995

and by

Analytical Results

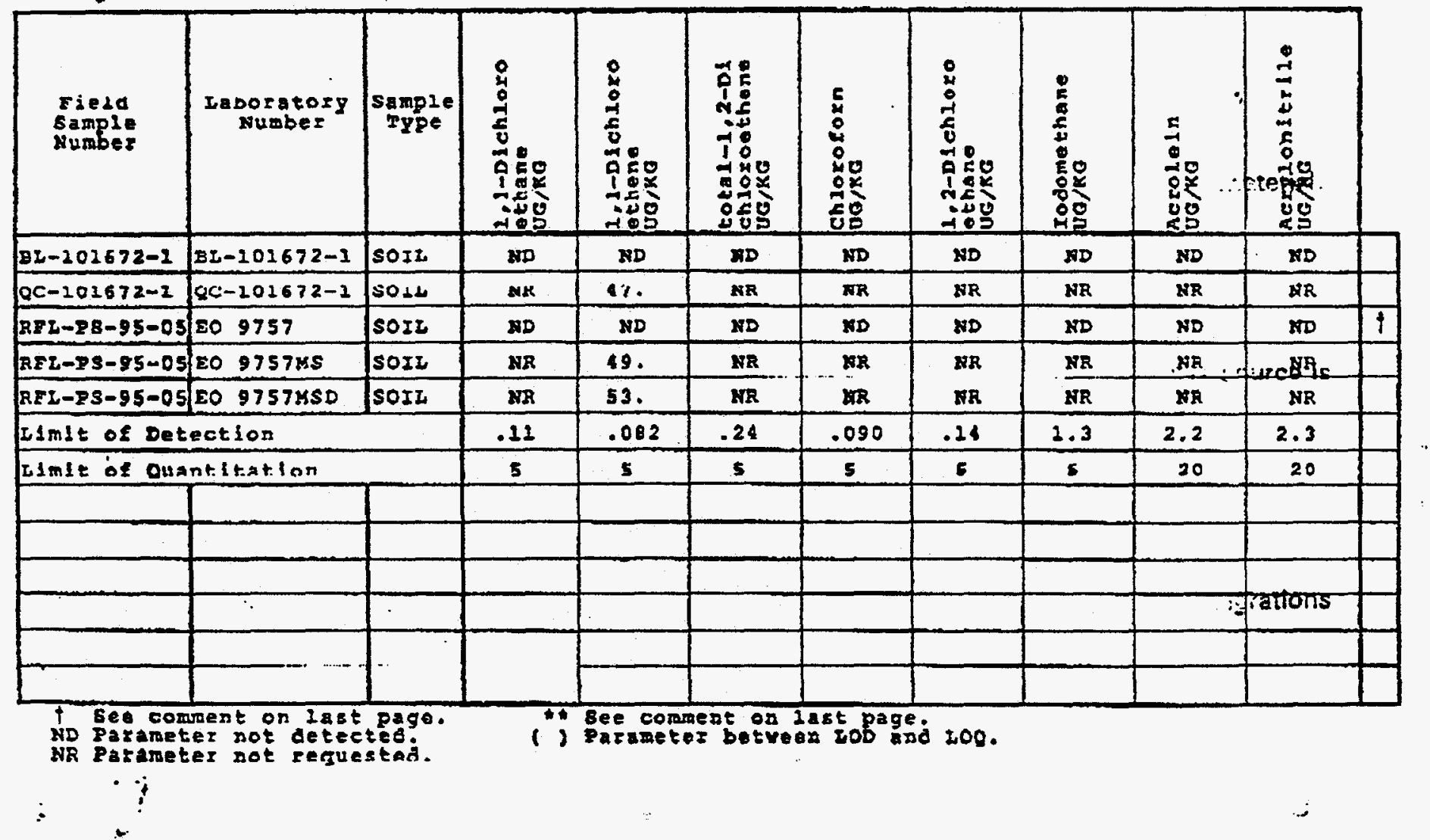




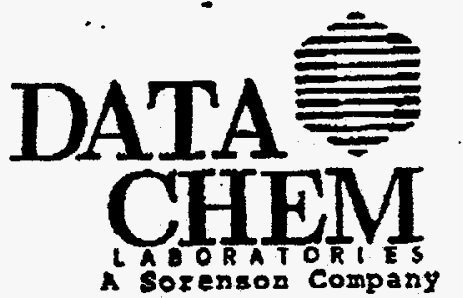

MK-Ferguson Company

P.0. Box 151

Rifle, Co 81650

Attention: Kathy Benson
ANALYTICAL REPORT FOII ARE-AL

Page 3 of 7

Part 3 of 6

Date OCT 18 1995

Agency Ident111cation Number $\$ 95-1106-C E$

Account No. 03018

FAX (303) 625-4623

Telephone

Sampling Collection and Shipment

Sampling sito

Date of Colleotion Oatober. 03, 1005

Date Samples Recelved at Laboratory latober 04.1995

Analysis

Method of Analysis EPA 8240

Date(s) of Analysis October 09, 1995

Analytical Results

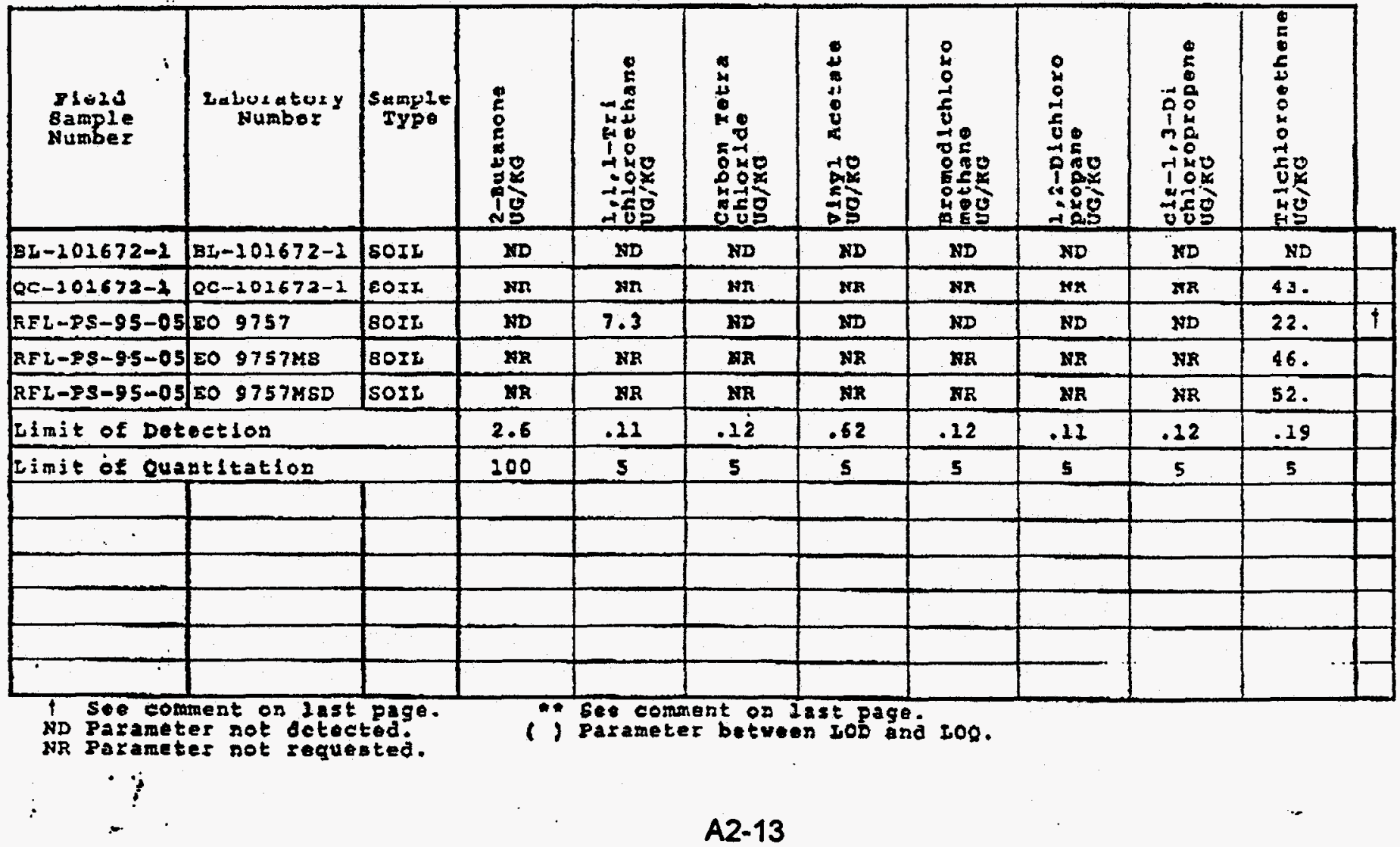




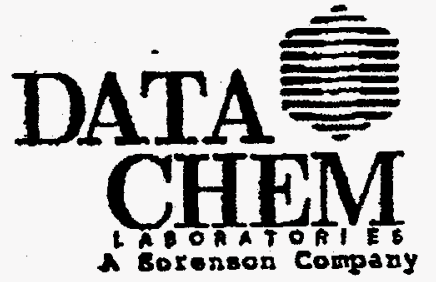

ANALYTICAL REPORT

Form ARF-AL

Page 4 of 7

Part 4 of 6

Date OCT 161995

MR-Ferguson Company

P.0. Box 151

Rifle, $C 081650$

Attention: Kathy Benson

FAX (303) $625-6623$

Telephone

Agency Identification Number $\$ 95-1106$ - CE

Account No. 03018

Sampling collection and Shipment

Sampling site

Date of Collection Datober 03, 1095

Date Samples Received at Laboratory October 04,1995

Analysis

Method of Analysis ERA 8240

Date(s) of Analysis Detober 09, 1995

Analytical Results

\begin{tabular}{|c|c|c|c|c|c|c|c|c|c|c|}
\hline $\begin{array}{l}\text { Fleld } \\
\text { Sampie } \\
\text { Number }\end{array}$ & $\begin{array}{c}\text { Iaboratory } \\
\text { Nuxber }\end{array}$ & $\begin{array}{l}\text { Sample } \\
\text { rype }\end{array}$ & 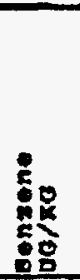 & 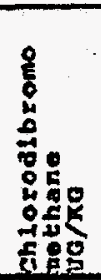 & 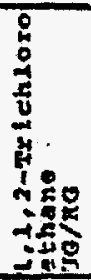 & 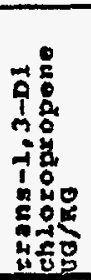 & 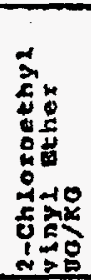 & 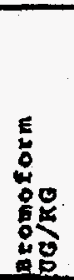 & 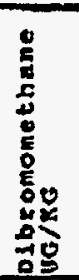 & 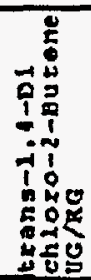 \\
\hline $82-101672-2$ & $B 2-201672-2$ & soiz & $m$ & ED & $\mathrm{nd}$ & ND & $\mathrm{ND}$ & MD & ND & ND \\
\hline $8 c-101672-1$ & $0 c-101672-1$ & soI2 & 47. & BR & MR & MR & $\mathrm{mR}$ & MR & $2 \pi R$ & NR \\
\hline BSI SE-95-0 & 1809757 & 10025 & 50 & 20 & an & ND & MD & MD & 80 & UD \\
\hline RFL-PS -95-05 & 20075748 & sors & 47. & $\mathrm{NR}$ & $\mathrm{gR}$ & $28 R$ & NR & NR & $\mathrm{FR}$ & NR \\
\hline$R=L-P S-9)^{\circ}-05$ & $209757 \mathrm{MSO}$ & soI2 & 50. & Mn & $\boldsymbol{E n}$ & QR & MR & NR & XR & NR \\
\hline Ilmit of Det & sectlon & & .21 & .20 & .22 & .23 & .20 & .10 & .22 & .68 \\
\hline Llmit of Qua & lnt1tat10n & & 5 & 5 & 5 & 5 & 10 & 5 & 5 & 5 \\
\hline & & & & & & & & & & \\
\hline & & & & & & & & & & \\
\hline & & & & & & & & & & \\
\hline & & & & & & & & & & \\
\hline & & & & & & & & & & \\
\hline & & & & & & & & & & \\
\hline
\end{tabular}

A2-14

960 West LeVoy Drive / Salt Lake City, Dtah 84123-2547/(801) 266-7700 3ी A Sorenson Company 


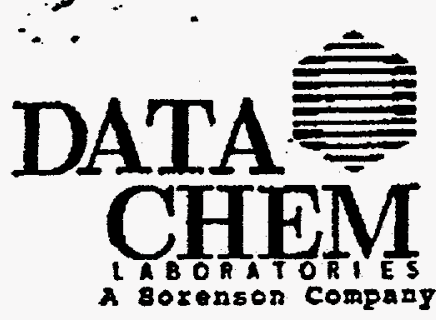

MK-Ferguson Company

P.0. BOx 151

Rifle, CO 81650

Attention: Kathy Beuson
ANALYTICAL REPORT FOTM ARF-AI

Page 1 of 2

Part 1 of 1

\section{Date SIP 131995}

Agency Identification Number v95-0020-CR Account No. 03020

\section{Telephone}

FAX (303) $625-4623$

Sampling Colleotion and Shipment

Sampling Site

Date of Collection August 30, 1995

Date Samples Recelved at Laboratory August 31, 1995

Aralysis

Method of Analysis $8020 \mathrm{MOD}$

Date(s) of Analysis September 12, 1995

Analytical Results

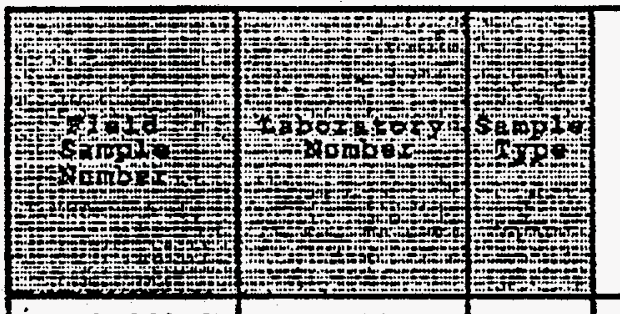

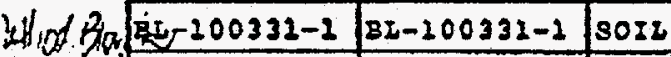

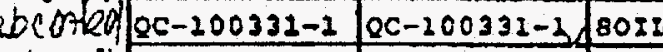

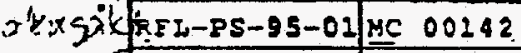

riek spicary-ps-95-0iluc 0021927\%

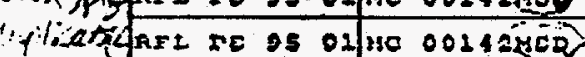

Out $d \rightarrow R F L-P S-95-02$ MC 00143

RFL-RS-95-03/MC 00144

8025

sors
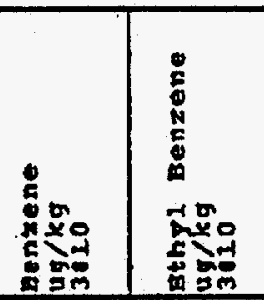

:

$\mid$

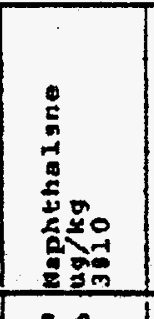

WD 1 MD 19.8

\begin{tabular}{|l|l|l|} 
wD & 1.5 & WD \\
\hline 360
\end{tabular}

\begin{tabular}{l|l|l|}
\hline 360 & 390 & 370 \\
\hline
\end{tabular}

r.

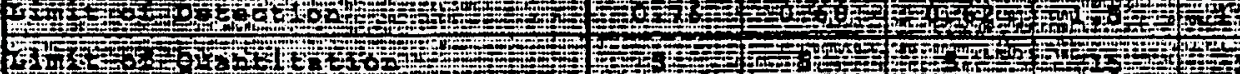

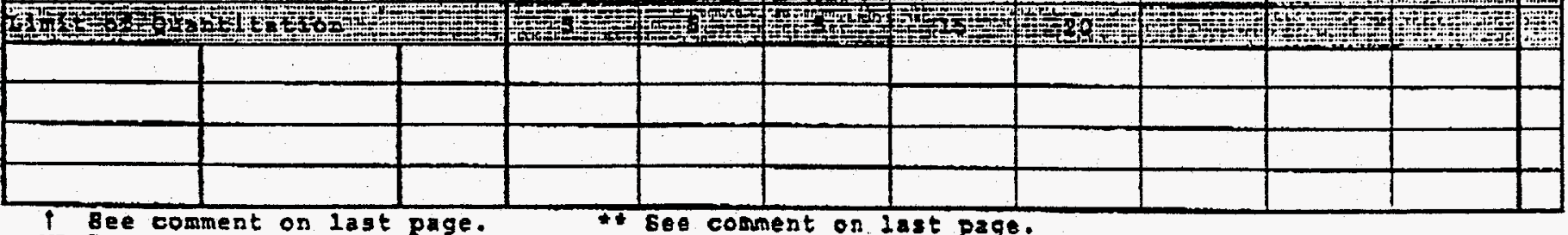

ND Bee comment on last page.

ND Parameter not detected.
NR Parameter not gequestad.

$400 \mathrm{ug} / \mathrm{kg}$ \#TE
$1200 \mathrm{~kg} / \mathrm{kg}$.

() Parameter botwoon zob and soo.

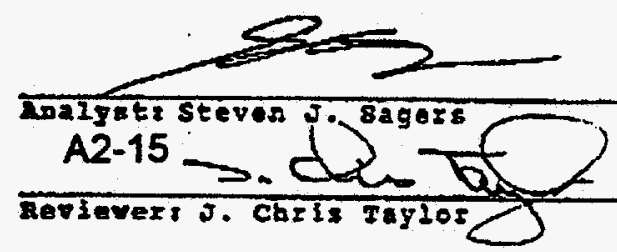




\title{
DATA

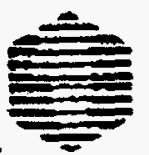

ANALYTICAL REPORT
Form ARF-AL

Page 1 of 2

Part 1 of 1

\author{
Date SEP $25 t 995$ \\ Agency Identification Number $495-0020-A R$ \\ Account No. 03020
}

M-Ferguson Company

P.0. Box :151

Rifle, $C 0 \delta: 6: 0$

Attention: Kathy Benson

FAX (303) 625-4623

Telephone

Sampling Collection and Shipment

Sampling site

Dale of Collection August 30,1995

Date Samples Received at Laboratory August 31, 1995

Analysis

Method of Analysis OC-DC-TRHD

Date(s) of Analysis September 15, 1995 - September 19, 1095

Analytical Results

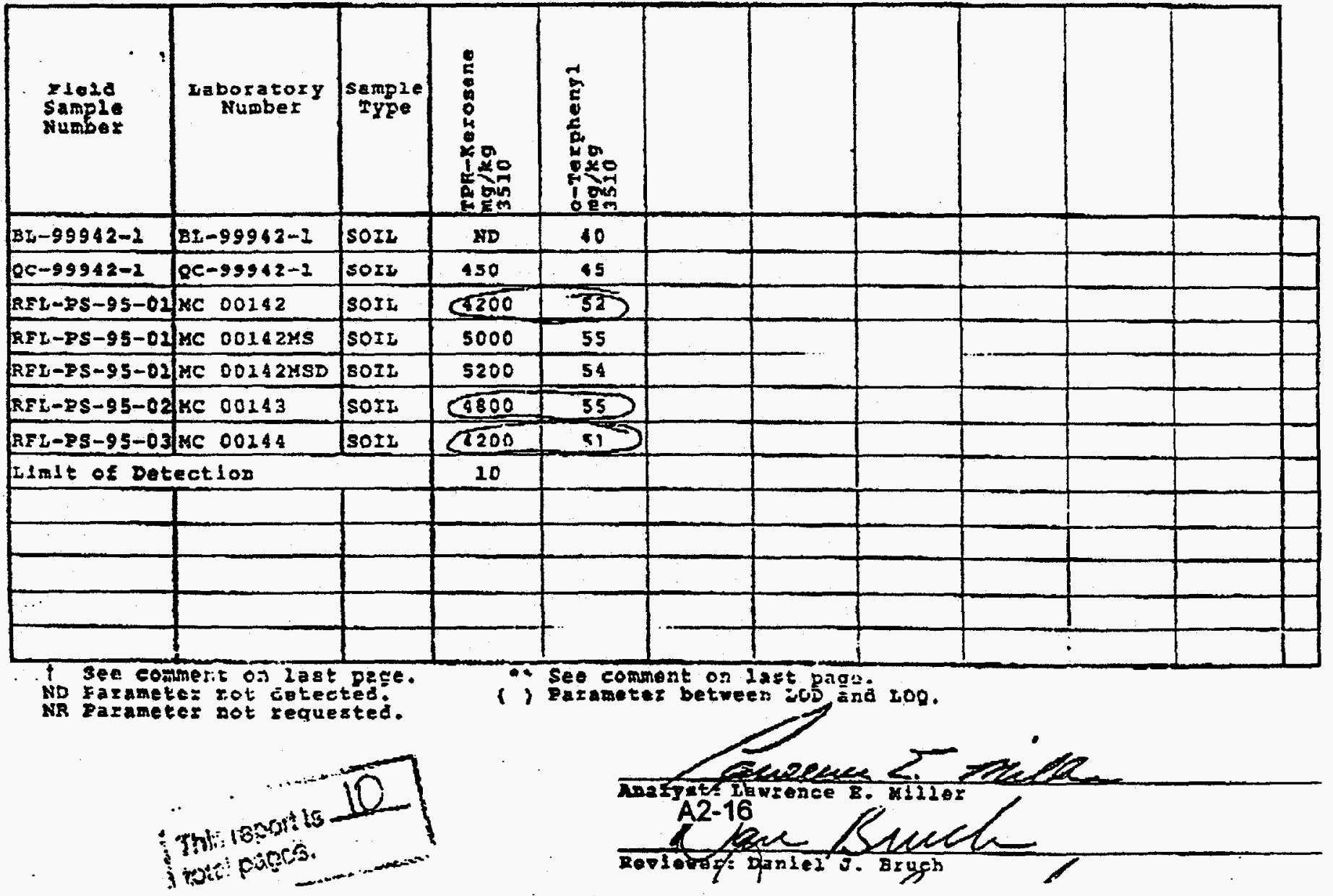


ATTACHMENT 3

FINAL GRADING PLAN 


\begin{tabular}{|c|c|c|c|}
\hline 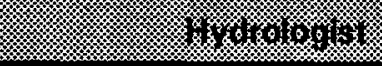 & 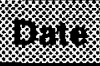 & 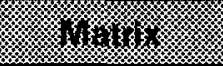 & Ground Water \\
\hline TMonks & & 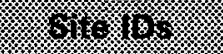 & RFN-01 \\
\hline 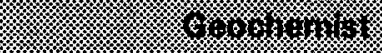 & 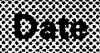 & 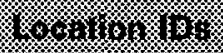 & ooox \\
\hline DErskine & & 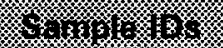 & Enter in table at bottom \\
\hline
\end{tabular}

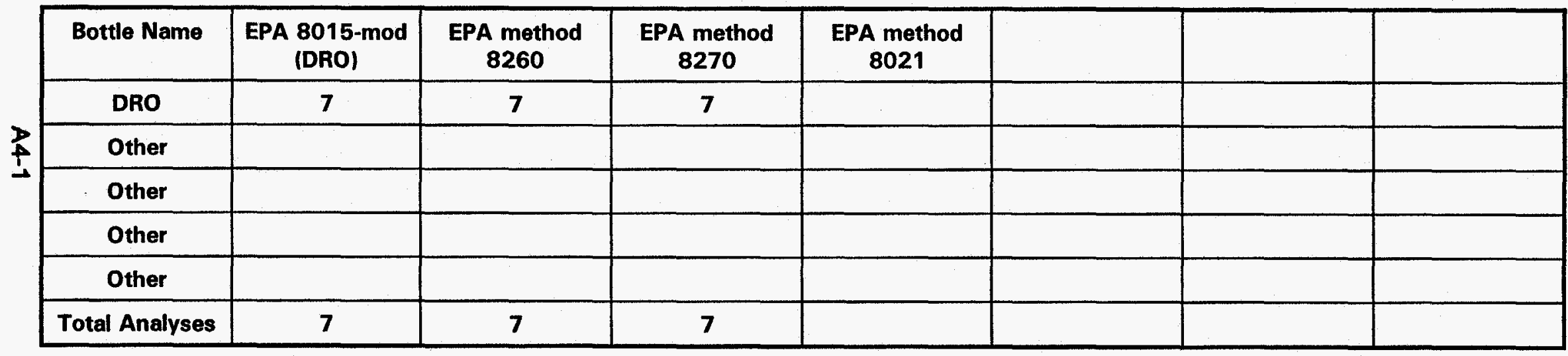

\begin{tabular}{|llllll|}
\hline RFN01-655-0001 & RFN01-656-0001 & RFN01-657-0001 & RFN01-658-0001 & RFN01-659-0001 & RFN01-659-0002 \\
RFN01-999-0001 & & & & & \\
& & & & & \\
& & & & & \\
\hline
\end{tabular}




\section{WORK ORDER PLAN - CHEMICAL ANALYSIS OF UMTRA TAC SAMPLES}

SAMPLE MATRIX: Ground Water

SITE HYDROLOGIST: TMOnks

NAME (print) SIGNATURE

SITE GEOCHEMIST: DErskine

NAME (print)

SIGNATURE

DATE
SITE ID(s): RFN-01

LOCATION ID(s): See Below

SAMPLES ID(S): 000X

\begin{tabular}{|c|c|c|c|c|c|c|c|c|c|c|c|c|c|c|c|c|c|c|c|c|c|c|c|c|c|}
\hline $\begin{array}{l}\text { Bottle } \\
\text { Name }\end{array}$ & $\mathrm{Cl}$ & $\mathrm{SO}_{4}$ & $\mathrm{Na}$ & $K$ & $\mathbf{M g}$ & $\mathrm{Ca}$ & $B$ & $F$ & CN & $s$ & TKN & $\mathrm{NH}_{4}$ & $\begin{array}{c}\mathrm{NO}_{3} \\
\& \\
\mathrm{NO}_{2} \\
\end{array}$ & $\mathrm{NO}_{3}$ & $\mathrm{SiO}_{2}$ & $\mathrm{PO}_{4}$ & $\mathrm{Br}$ & Al & $\mathrm{Sb}$ & As & $\mathrm{Ba}$ & $\mathrm{Be}$ & $\mathrm{Cd}$ & $\mathrm{Cr}$ & Co \\
\hline A-1 & $x$ & $x$ & & & & & & $x$ & & & & & & & & & & & & & & & & & \\
\hline$M-2$ & & & $x$ & & $x$ & $x$ & & & & & & & & & & & & & & $x$ & & & & & \\
\hline $\mathrm{N}-1$ & & & & & & & & & & & & $x$ & & $x$ & & & & & & & & & & & \\
\hline & & & & & & & & & & & & & & & & & & & & & & & & & \\
\hline & & & & & & & & & & & & & & & & & & & & & & & & & \\
\hline & & & & & & & & & & & & & & & & & & & & & & & & & \\
\hline & & & & & & & & & & & & & & & & & & & & & & & & & \\
\hline $\begin{array}{l}\text { Total \# } \\
\text { of Tests }\end{array}$ & 8 & 8 & 8 & & 8 & 8 & & 8 & & & & 8 & & 8 & & & & & & 8 & & & & & \\
\hline
\end{tabular}

COMMENTS:

Please analyze samples RFN01-655-0001, RFN01-656-0001, RFN01-657-0001, RFN01-658-0001, RFN01-659-0001, RFN01-659-0002, RFN01-999-0001 and RFN01-999-0003. 





ATTACHMENT 4

WORK ORDER 